\title{
NEGATIVE GEOLOGY: HUMPHRY DAVY AND FORMING THE ROYAL INSTITUTION'S MINERAL COLLECTION, 1803-1806
}

\author{
FRANK A. J. L. JAMES \\ Department of Science and Technology Studies \\ University College London \\ Gower Street \\ London WC1E 6BT \\ and \\ Royal Institution \\ 21 Albemarle Street \\ London, WIS $4 B S$ \\ England \\ fjames@ri.ac.uk
}

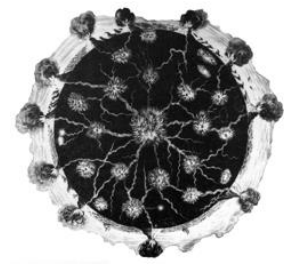

Earth Sciences History Vol. 3x, No. x, 201x pp. $x x x-y y y$

\begin{abstract}
This paper discusses Humphry Davy's geological interests and the formation of the Royal Institution's mineral collection during the early nineteenth century. Compared to other aspects of Davy and the Royal Institution, both these topics have been comparatively neglected in historical studies. The evidence supports the argument that applying scientific knowledge and method to practical problems was very difficult at the time. This suggests, despite the hopes entertained for it, that geology and mineralogy did not then contribute to the process of industrialisation, except in a negative manner. This failure may explain why the Royal Institution did not develop its mineral collection following initial enthusiasm.
\end{abstract}

Keywords: Humphry Davy, Royal Institution, nineteenth century, geology, mineralogy, collecting, Cornwall, Ireland, lecturing, science and practice, scientific rhetoric, industrialisation doi:

\section{INTRODUCTION}

One of the great vignettes of early nineteenth-century Romanticism is the ascent of the third highest mountain in England, Helvellyn, by William Wordsworth (1770-1850), Walter Scott (1771-1832) and Humphry Davy (1778-1829) on 14 August 1805 (Reed 1975, p. 297). Of this climb Scott retained fond memories, ${ }^{1}$ Wordsworth, who had strong geological interests (Wyatt 1995), commented on the difficulty in expressing his feelings standing 'on its summit with two such men as Davy and Scott' (Lockhart 1837-1838, 2: 71), while Davy recorded in his notebook that the summit was made of greywacke. ${ }^{2}$ Though Davy retained much of his early Romantic sensibilities and personal connections, neither his distinguished companions, nor the landscape's sublimity then engaged his attention, but the mountain's geology and mineralogy did engage him.

This episode captures neatly that geology, with its various knowledge forms, had become, and would remain for the rest of his life, one of Davy's primary scientific interests. His biographical literature has concentrated mostly on his chemical and electrical researches while, in comparison, less has been written about his geological and mineralogical studies. ${ }^{3}$ Generally regarded as a chemist, this description may explain why Davy has been neglected by historians of geology. When discussed in that literature, with the honourable exception of a paper by David Knight (2009), it is

Walter Scott to Jane Apreece, 2 April 1811, Grierson (1932-1937 2: 496-470)..

RI MS HD/15/G, p. 80 .

For some brief discussions of Davy's geological work see Hartley (1966, pp. 101-103, 122-124); Knight (1992 / 1996, pp. 55-56). 
usually either in the context of his difficulties with the Geological Society following its founding in 1807 (Rudwick 1963, 2005, p. 464, Herries Davies 2007, pp. 22-23) or with his role in turning the interests of Roderick Murchison (1792-1871) from fox hunting to geology (Stafford 1989, p. 6). However, four of Davy's 1805 Royal Institution geological lectures have been published by Alexander Ospovat (1978), while Robert Siegfried and Robert Dott (1980) republished those together with a further six. In terms of analysis, Steven Yearley (1985) discussed Davy's lectures in detail, and Siegfried and Dott (1976) wrote more generally about Davy's geological interests. ${ }^{4}$ Sally Newcomb $(1990,2009)$ using mainly printed sources which include, of course, extracts from letters and notebooks has discussed his experimental work, while Rachel Laudan (1987, pp. 185187) and Haraldur Sigurdsson (1999, pp. 160-169) have explored Davy's chemical theory of volcanic activity and its influence which belongs to a (slightly) later stage of his career.

It is also possible that the neglect of Davy's geology could be attributed to the extensive studies undertaken in recent decades of the history of geology during first half of the nineteenth century which have concentrated principally on stratigraphy and palaeontology. Such studies, doubtlessly undertaken with a view to understanding the development of the evolutionary theories proposed by Charles Darwin (1809-1882), have had the consequence, I would suggest, of permitting the comparative historical neglect of mineralogy and of chemical geology - precisely the areas in which Davy worked. Yet I suspect to a savant alive in 1800, say, the study of strata would not have appeared as obviously the most significant part of the fledgling science of geology. All told, the limited extent of the literature is a bit surprising given that Davy's notebooks are full of observations and sketches of geological features.

It is not a new observation that much effort by early geologists went into mineralogy. Paul Weindling (1979) in his study of the Geological Society's prehistory made much the same point, as more recently has Shelley Trower $(2014$, p. 21$)$ in her paper dealing mostly with Davy and Cornwall. There have been some historical studies of mineralogy, most notably by Laudan (1987), and there is a useful category of texts that provide detailed catalogues of mineral collections and where the specimens went, though they don't consider what the point of all this activity might have been (Cleevely 1983; Wilson 1994).

Davy was also primarily responsible for forming a mineral collection displayed at the Royal Institution, where he worked as Professor of Chemistry from 1802 to 1812 and for which he undertook three extensive mineral collecting expeditions around Britain and Ireland between 1804 and 1806. The Royal Institution's mineral collection has been even less studied than Davy's geology. Morris Berman (1978, pp. 88-92) in his now dated book discussed it in terms of the relevance of mining to landowners who, he claimed, played a dominant role in the early Royal Institution. $^{5}$

Here issues surrounding the relationship of industrialisation and geological science raise their head. Writers such as Berman but also Trower (2015, pp. 26-56) and Hugh Torrens (2017, p. 79) assert that they were related closely, but the link is seldom, if ever, made apparent. Was scientific knowledge or method successfully applied to locating valuable mineral deposits, in which case what are the examples at the time? Certainly, the wealthy Midlands engineer and businessman James Watt (1736-1819), drawing on his extensive knowledge of Cornish mining, thought that mineralogy did not 'advance' business. ${ }^{6}$ However, the negative of this presumed relationship did then exist in the various and sometimes confusing or conflicting forms of geological knowledges which on occasion misled mineral prospectors into fruitlessly expending significant resources as documented by Torrens in two instances $(1997,1998)$. Another negative use of geology occurred in the 1810s when Davy used his knowledge to play down, tactfully, the potential mineral value of the Dunrobin estate owned by George Leveson-Gower, Marquess of Stafford (1758-1833). ${ }^{7}$ Or were industry and geology related through the development of mining, canals and later railways exposing geological phenomena that would otherwise have remained buried? Or is the relationship

See also Siegfried (1980, especially pp. 182-193).

For a corrective see James (2015).

James Watt sr to James Watt jr, 3 October 1790, LoB MS 3219/6/1/77.

Humphry Davy, 'Sketches of the Geology of the East Coast of Sutherland', NLS MS Dep 314/16. 
contingent in that some actors who happened to be land and/or mine owners also had an interest in the science which superficially might seem linked to their business interests? That does not necessarily mean, however, as Berman claimed, that business interests were their sole motivation for pursuing the expensive hobby of mineral collecting.

If there then existed a relationship between industrialisation and geology it was by no means straightforward, but really a specific instantiation of the more general problem that applying scientific knowledge and method developed in the relatively controlled environments of the laboratory and the study for useful and practical purposes was then, and for that matter still is, very difficult. Hence the limited contribution that science made to industrialisation in the eighteenth and well into the nineteenth centuries. ${ }^{8}$ Davy at some level seems to have recognised the problems involved at least in some areas. To circumvent them he invoked, as he did elsewhere, the rhetorical notion of the infancy of a science. ${ }^{9}$ The inference being that with more study and research scientific knowledge and method would, at some point, become useful. The questions raised, even before any answers are suggested, already illustrate the deep complexity of any relationship that might exist between geology and industry. This paper will examine some of the issues raised through discussing Davy's career and the early Royal Institution's development.

\section{HUMPHRY DAVY}

For nearly twenty years after his birth in Penzance in 1778, Davy lived in the far west of Cornwall. Possessing an enormous range of minerals, the county enjoyed, during Davy's lifetime, global preeminence for extracting tin and copper ores. Indeed, Davy's father went bankrupt following some unwise mining investments and died on 10 December 1794, a week before his son's sixteenth birthday leaving four younger siblings and debts of $£ 1300 .{ }^{10}$ Davy’s mother opened a milliner's shop, took in lodgers and apprenticed her son to the Penzance surgeon and apothecary John Borlase (1753-1813), ${ }^{11}$ though it would appear that Davy was more interested in writing poetry than practicing pharmacy (Amin 2013; Ruston 2013)

Davy might well have remained in provincial obscurity had it not been that the war against Revolutionary France, in its fifth year at the end of 1797, made it difficult for the wealthy to go to the usual places on the Continent for the sake of their health. Of particular concern in October 1797 to James Watt was the health of his youngest son Gregory Watt (1777-1804), whose sister had died of consumption three years before. After explicitly ruling out Gregory going to Saxony or Naples, Watt sr commented to his other son, James Watt jr (1769-1848), that 'we must content ourselves with Cornwall', ${ }^{12}$ which the Birmingham physician William Withering (1741-1799) recommended for him. ${ }^{13}$ Cornwall, Watt sr added, would have the advantage that Gregory could participate in Boulton and Watt's extensive steam engine business in the county. Accordingly, in mid-November, Watt sr sent Gregory detailed 'Instructions' directing him to fix his 'quarters in Penzance', whom he should meet, what visits he should make, adding despite his views, that his son should study Cornish minerals and ores and so on. ${ }^{14}$ Noting in a later letter that 'sincerity is not a Cornish virtue', he added that Gregory should cultivate Davies Giddy (1767-1839), a minor member of the Cornish gentry, sometime High Sheriff of the county, but exercise caution. ${ }^{15}$ The reason for the elder Watt's concern was the pirating (as he saw it) of his steam engine design by Cornish engineers such as Jonathan Hornblower (1753-1815).

\footnotetext{
8 There were exceptions, of course, such as (possibly) Watt's separate condenser and Wedgwood's controlled ceramic experiments. In the 1820 s Davy experienced severe difficulties in applying electro-chemical science. See James (1992).

Humphry Davy, 'Sketches of the Geology of the East Coast of Sutherland', NLS MS Dep 314/16. For another example see James (2015).

Katherine Davy recollection, nd but early 1830s, RI MS HD/26/D/80, p. 1.

Davy's indenture of apprenticeship, dated 10 February 1795, RI MS HD/5/3.

James Watt sr to James Watt jr, 21 October 1797, LoB MS 3219/6/1/126. Published in Tann (1981, pp. 239-240).

James Watt sr to Joseph Black, 7 February 1798, Anderson and Jones (2012, 2, letter 789).

James Watt sr, 'Instructions for G. Watt', 15 November 1797, LoB MS 3219/4/118/48.

James Watt sr to Gregory Watt, 26 December 1797, LoB MS 3219/7/1/34.
} 
Arriving in Truro at the end of November ${ }^{16}$ Gregory spent a few days staying with Watt's agent Thomas Wilson (1748-1820), before travelling to Penzance for a couple of days to secure accommodation. He found lodgings were 'neither plentiful nor cheap.-At length however I found a very decent parlour and bedroom in the house of an old or rather elderly lady who bears an exceeding good character'. ${ }^{17}$ This was Davy's mother, then aged about 45, with whom he would stay until March when he moved to Redruth. ${ }^{18}$ After a few days undertaking business centred on Truro, Gregory returned to Penzance on 19 December 1797, just after Davy's nineteenth birthday. ${ }^{19}$

According to the much later recollection by Davy's sister Katherine Davy (1781-1860), Gregory, just a year older than Davy, became one of the family. ${ }^{20} \mathrm{He}$ and Davy would ramble, presumably on his days off, about the countryside collecting minerals, on which Gregory spent $£ 10$ $4 \mathrm{~s} 6 \mathrm{~d} .{ }^{21}$ The following year Gregory wrote for William Withering jr (1776-1832) a twelve page sketch about Cornish minerals demonstrating the extensive journeys that he made around Cornwall, though not mentioning Davy's presence. ${ }^{22}$ Davy and Gregory read Elements of Mineralogy (1784 and 1794-1796) by Richard Kirwan (1733-1812) ${ }^{23}$ which Gregory used to guide his mineral classification, ${ }^{24}$ and visited mines as Gregory had been enjoined to do by his father (Davy 1836, 2: 44-46). More than thirty years later Watt jr recollected that Gregory 'was pleased with his [Davy's] talents and disposition and took pains to direct his studies ... and spoke of him among his friends as an extraordinary young man'. ${ }^{25}$ These friends included Tom Wedgwood (1771-1805) and John Wedgwood (1766-1844), sons of the late wealthy Midlands potter Josiah Wedgwood (1730-1795), also wintering in Penzance for the sake of their health. ${ }^{26}$

Davy (1800, p. 453) later recalled that he began studying chemistry in March 1798, around the time Gregory departed for Redruth. Davy's recollection is supported both by his sister's account ${ }^{27}$ and by the absence of chemistry in his earliest surviving notebooks. ${ }^{28} \mathrm{He}$ read (in French, which he learnt from an émigré (Paris 1831,16)) the Traité élémentaire de Chimie (first published in two volumes in 1789 with a second edition in 1793) by Antoine Lavoisier (1743-1794) and $A$ Dictionary of Chemistry by William Nicholson (1753-1815) (Davy 1836, 1: 42). Furthermore, Davy also undertook some chemical experiments (Davy 1836, 1: 43-4) and it seems those contributed towards drawing him to Giddy's notice rather than his acquaintance with Gregory or the Wedgwood brothers. As Giddy told Thomasina Dennis (1770-1800), an aspiring writer to whom he taught Greek and Latin,

I was first introduced to his acquaintance by Mr. John Dennis and never felt myself more surprised on discovering a young man situated in all respects so disadvantageously as Mr. Davy prosecuting experiments and investigations worthy of Doctor Priestly. I could not but be the more astonished, perfectly remembering his late father ${ }^{29}$

This account (rather uncomplimentary towards Davy's father) agrees well with Katherine Davy's recollection that Davy showed 'Mr John' (by 1835 'one of the oldest inhabitants of Penzance' (Davy 1836, 1: 48)) some experiments that he had been doing in the house of Davy's early patron,

\footnotetext{
16 Gregory Watt to James Watt sr, 2 December 1797, LoB MS 3219/7/49/2.

17 Gregory Watt to James Watt sr, c.15 December 1797, LoB MS 3219/7/49/3.

18 Gregory Watt to James Watt jr, 1 April 1798, LoB MS 3147/3/76/6.

19 Gregory Watt to James Watt sr, 20 December 1797, LoB MS 3219/7/49/4.

$20 \quad$ Katherine Davy recollection, 4 January 1831, RI MS HD/26/D/75, p. 1.

21 Gregory Watt's account book, LoB MS 3219/7/22 (unpaginated). See Humphry Davy to Grace Davy, 11 October 1798, RI MS HD/26/A/1 for his collection.

Gregory Watt, 'Sketch of the Mineralogy of the County of Cornwall', October 1798, LoB MS 3219/7/28/12-14.

Gregory Watt to James Watt sr, 19 January 1798, LoB MS 3147/3/76/3.

Gregory Watt to Matthew Boulton, 7 March 1799, LoB MS 3782/13/39/072.

James Watt jr to John Craig, 24 September 1831, RI MS HD/26/D/67.

Gregory Watt to James Watt jr, 6 December 1797, LoB MS 3219/6/1/137.

Katherine Davy, Recollection, 4 January 1831, RI MS HD/26/D/75, p. 1.

Both of these are from the mid-1790s. RI MS HD/13/F dealt mostly with general philosophical topics while RI MS $\mathrm{HD} / 21 /$ A principally contains mathematical exercises.

29 Davies Giddy to Thomasina Dennis, 17 November 1798, CRO DG/87/1/20.
} 
John Tonkin (circa 1719-1801). Dennis did not understand them but offered to introduce Davy to Giddy. ${ }^{30}$

Although we don't know when this introduction was made, it proved decisive for Davy since Giddy actively supported talented Cornish people, Hornblower and Dennis being good examples. For instance, as a result of meeting the Wedgwoods when they were in Penzance, Giddy secured for Dennis a position with them as governess, not an especially successful episode (Woof 1962).Thus Giddy's patronage of Davy was well in line with his normal practice and he gave him access to his library at his house Tredea, a few miles north east of Penzance; doubtless he also lent him books as he had to Gregory Watt. ${ }^{31}$ He introduced Davy to John Edwards (1731-1807) who managed the Cornish Copper Company at Hayle on the coast to the north east of St Erth. The Company's works possessed a well-equipped laboratory where Davy expressed 'tumultuous delight on seeing, for the first time, a quantity of chemical apparatus, hitherto only known to him through the medium of engravings' (Paris 1831, 1: 47).

\section{THE MEDICAL PNEUMATIC INSTITUTION}

Giddy played a key role in successfully recommending Davy to his former teacher at Oxford University, the radical (Jacobin) physician Thomas Beddoes (1760-1808), as the ideal person to be appointed Superintendent of the Medical Pneumatic Institution in Bristol. Beddoes, following his enforced departure from Oxford in 1792, had spent much time raising subscriptions for this institution. Its object was to investigate if any of the gases discovered during the eighteenth century possessed therapeutic properties (James 2016). By mid-1798 he deemed that he had sufficient money to start and began actively searching for a Superintendent. Both Giddy and Gregory Watt successfully recommended Davy's appointment; aged nineteen he arrived in Bristol to take up this position in October 1798.

Davy's duties included establishing the Institution in its building, but because of slow progress, he had time for other activities and indeed with some of those he partially subverted the original intentions behind the institution (James 2017). For example he continued his mineralogical pursuits, quickly asking his mother to send his collection from Penzance. ${ }^{32}$ In Bristol he initially collaborated with the somewhat obscure William Clayfield (1772-1837). ${ }^{33}$ After the death of their father (1787) and mother (1798), Clayfield joined a partnership with his brother (who had married well) in the family distilling business based in Castle Street, Bristol. ${ }^{34} \mathrm{~A}$ brief notice after his death described him as 'a gentleman of high philosophic and scientific attainments, having from a very early period devoted all his leisure time to the acquisition of knowledge, chiefly in the several departments of chemistry, botany, mineralogy, and geology'. ${ }^{35}$ Quite where he acquired his knowledge is not known, but by the mid-1820s his mineral collection became sufficiently well known to be mentioned, albeit briefly, in a Bristol guidebook (Evans 1825?, p. 89). In a letter to Giddy written very shortly after his arrival in Bristol Davy referred to Clayfield as 'our friend' suggesting an already existing acquaintance. ${ }^{36}$

Clayfield had, for the first time in England, found at Aust (on the banks of the Severn, north of Bristol) a large seam of sulphate of strontian, a mineral only discovered in Scotland during the early 1790s (Hope 1793). Delays in publishing Clayfield's discovery meant others announced it first, and Davy helped support Clayfield's priority (Fullmer 2000, pp. 197-199). Davy's support partly involved sending samples of the mineral to friends such Henry Penneck (1761-1834) a medic

Katherine Davy, Recollection, 4 January 1831, RI MS HD/26/D/79, p. 3r-v.

Davies Giddy to Gregory Watt, 20 January 1798, LoB MS 3219/7/5/53.

Humphry Davy to Grace Davy, 11 October 1798, RI MS HD/26/A/1.

Knight (1992 / 1996 p. 51) gave his forename as Thomas.

The dissolution of the partnership was noted in The London Gazette, 5 September 1826, p. 2167.

The Bristol Mirror, 4 March 1837, 3g.

Humphry Davy to Davies Giddy, 12 November 1798, Paris (1831, 1: 64-66). Giddy had known Clayfield since at least 1787 when he visited him in Bristol and had dined with him in Oxford in 1789. Giddy, Diary, 7 and 8 July 1787 and 1 May 1789, CRO DG 14. 
in Penzance ${ }^{37}$ and when in the Midlands during mid-January 1799 he promised to send Gregory Watt a specimen of sulphate of strontian. ${ }^{38}$

Following the completion of the Medical Pneumatic Institution's laboratory, Davy's mineral work came to a halt in March. During April he began experimentation on dephlogisticated nitrous air as Joseph Priestley (1733-1804), its discoverer, had named it, or nitrous phosoxyd as Davy initially termed it before finally calling it, following Lavoisierian nomenclature, nitrous oxide. Davy mostly spent the following twelve months determining its chemical and especially its extraordinary physiological properties, and published his results in July 1800 (Davy 1800). Because of his close association with Beddoes, Davy also became subject to attack by government supporters, being roundly condemned in the Anti-Jacobin Review in August 1800 (Anonymous 1800). With possibly only limited resources available for continuing the Medical Pneumatic Institution, the attack may have prompted him to think about his future career prospects and in March 1801 he moved to the recently founded Royal Institution in London.

\section{THE ROYAL INSTITUTION}

The Royal Institution had been established in 1799 at a meeting held at the Soho Square house of Joseph Banks (1743-1820), President of the Royal Society of London. The meeting comprised a group of wealthy gentlemen (the Proprietors) who each contributed fifty guineas, a substantial sum, to found the new institution. They had a variety of agendas about promoting science through lectures and providing scientific advice with a general utilitarian orientation. As one might expect from such a novel organisation, these were a rather underdefined set of ideas which, I have argued elsewhere, later allowed Davy considerable freedom of manoeuvre to do much as he pleased, including not providing lecture courses he had been 'instructed' to deliver (James 2017, pp. 284 285). The Institution's first Professor, Thomas Garnett (1766-1802), had formerly lectured at the Andersonian Institution in Glasgow and brought some of its practices, especially about valuing the role of women in the audience, to London (Lloyd 2018, chapter 4). However, Garnett fell out with the Managers (the committee who ran the Royal Institution, subject to the audit of a Visitors committee) and with Benjamin Thomson, Count Rumford (1753-1814) who managed much of the Institution's routine affairs. It is clear that by appointing Davy in January 1801, the Royal Institution signalled the precarious tenure of Garnett's position and he resigned in June after being refused a pay rise. ${ }^{39}$

Despite not following at least some of the Managers' instructions Davy, unlike Garnett, survived by providing lectures attracting large fee-paying audiences (Lloyd 2018). With no previous lecturing experience, six weeks after he had joined the Royal Institution he delivered his first lecture in a course on the subject of galvanism, the plans for which he sketched out in a notebook within a couple of days of arriving at the Royal Institution. ${ }^{40}$ Those two pages were followed by notes written until the end of March describing various galvanic experiments. ${ }^{41}$ Not only did he make practical preparations for his lectures, but this research also resulted in his first paper to the Royal Society of London (Davy 1801a). As the poet and philosopher Samuel Taylor Coleridge (1772-1834) shrewdly noted, Davy must have made further discoveries in Galvanism since he would 'be puzzled to conceive how that subject could furnish matter for more than one Lecture' ${ }^{42}$ The pharmaceutical manufacturer William Allen (1770-1843) noted in his diary that Davy's first lecture was 'A most capital one.- He bids fair to rise high in the philosophical world' ${ }^{43}$ Presumably because of his success he soon repeated the series in the morning allowing 'people of rank and fashion' to attend and also delivered a course on pneumatic chemistry. ${ }^{44}$ Davy summarised

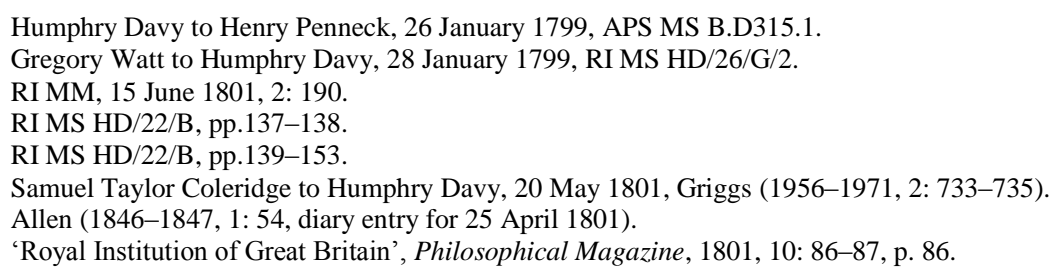


his galvanism lectures in a paper dated 1 September 1801 but not published until January 1802 (Davy 1802a). Until the following autumn he continued researching and publishing his electrical experiments (Davy 1802d, e, f, g), but then ceased further work for just over four years as he switched his primary interests to geology and mineralogy, ${ }^{45}$ though he continued to lecture on electricity but only as part of his chemical courses. It is a reasonable assumption that Davy had gone as far as he then could in exploiting the potential of electricity for his own fame. Furthermore, it was not easy to argue for the practical value of electricity, especially as he toned down for the Royal Institution audience (Davy 1804, p. 17) the early radical rhetoric he had deployed, at least in private, while in Bristol, when for example he had told Coleridge in late 1800 that he had 'made some important galvanic discoveries which seem to lead to the door of the temple of the mysterious god of Life'. ${ }^{46}$ It would be much easier for him to turn to geology and mineralogy where a strong practical rhetoric could be developed, even if nothing was delivered.

Davy's role at the Royal Institution brought him into contact with some of London's scientific practitioners and so he became acquainted with the very small societies they formed themselves into. Such groups, usually lasting only a few years and typically possessing significant overlapping memberships, met with varying degrees of informality ostensibly to discuss (what in modern terms would be regarded as) specialised scientific topics (Averley 1986; Lacey 2017; Weindling 1983). But since there existed no well-defined disciplinary boundaries, the subjects covered could be and were wide ranging. For instance, members of the British Mineralogical Society heard about chemistry and electricity. ${ }^{47}$ Its members included Allen, the physician and mineralogist William Babington (1756-1833) and William Pepys (1775-1856), a Royal Institution Proprietor. Just after Davy had finished his first course of lectures, Pepys introduced him at a meeting where he gave a couple of presentations, including on a new kind of eudiometer ${ }^{48}$ that he quickly published (Davy 1801b).

The month before the Society had offered to undertake the analysis of soils, at no charge, to aid 'the patriotic views of the Board of Agriculture' in improving farmland, an aim very much in line with Royal Institution's. ${ }^{49}$ One particular patriotic interest sought to improve the tanning of leather - an important material with many uses in the army and, to a lesser extent, the navy (Spiers 1968). At some point in June Davy told his old friend the tanner Thomas Poole (1766-1837) of Nether Stowey of the arrangement that he would deliver a course of lectures on tanning to the Royal Institution in the autumn. ${ }^{50}$ However, the Managers did not formally agree this until the end of the month when they authorised Davy to take leave of absence for the following three months so he could learn about tanning. ${ }^{51}$ Davy arrived in Bristol in mid-July from where he invited the Royal Institution Proprietor, painter and mineralogist Thomas Underwood (1772-1835) to join him 'to worship with me on the ancient altars of Cornwal[1]'.52 According to Underwood's diary he arrived in Penzance at the end of July ${ }^{53}$ and, according to another account possibly by him, they spent the next few weeks 'rambling along the sea coast and among the mines \& meadows of Cornwall' ${ }^{54}$ In mid-August George Greenough (1778-1855), accompanied by Davy's old school fellow Clement Carlyon (1777-1864), arrived in Penzance on the former's geological field trip to Cornwall. Greenough called on Davy; it would appear to have been their first meeting, since it confirmed

45

Russell (1963, p. 261) incorrectly ascribes to the requirements of the Royal Institution's Managers Davy's change of direction from electricity (or electro-chemistry as Russell somewhat anachronistically puts it) to mineralogy. Perhaps the outcome of not studying Davy's notebooks until four years after his first two papers on Davy's electrochemistry. Humphry Davy to Samuel Taylor Coleridge, 26 November 1800, Morgan Library and Museum, Misc English Coleridge, MA 1857. For example, Minutes of British Mineralogical Society, 29 October 1801 and 26 November 1801, NHM MS SC BRI, pp. 86-88 and 90.

Minutes of British Mineralogical Society, 14 May 1801, NHM MS SC BRI, pp. 79-80.

'British Mineralogical Society', Philosophical Magazine, 1801, 9: 282-283, p. 282. James (2015).

Thomas Poole to Josiah Wedgwood, 25 and 26 June 1801, WM MS MC 55.

RI MM, 29 June 1801, 2: 198.

Humphry Davy to Thomas Underwood, 12 July 1801, Davy (1836, 1: 148).

Published in Paris (1831, 1: 125).

Institut de France, MS H 155. 
Greenough in the 'favourable opinion' that Coleridge, who knew them both, had given of Davy. Davy told Greenough of his tanning experiments but that he was also working a good deal on mineralogy; during a long stroll along the coast he pointed out various mineral veins. ${ }^{55}$

At both the beginning and end of his stay, Davy visited Giddy, on the last occasion taking a drawing by Richard Trevithick (1771-1833), another Cornish engineer supported by Giddy, for Rumford at the Royal Institution. ${ }^{56}$ Visiting Poole at Nether Stowey on the way, he arrived back in London on 20 September ${ }^{57}$ During that month Poole's mother, Elizabeth, died, ${ }^{58}$ about which Davy told Coleridge, ${ }^{59}$ suggesting that Davy may not have had much opportunity to discuss tanning processes. Nevertheless, at a British Mineralogical Society meeting held at the end of October Davy provided two observations relating to tanning - again illustrating the eclectic interest of a group with an apparently specialist remit. Davy reported first that gallic acid did not accumulate in tan pits and second that green acorns did not contain tannin until heated to $212^{\circ} \mathrm{F} .{ }^{60}$ None of this would have been really sufficient to provide an entire lecture course on tanning at the Royal Institution and they were not given - possibly because with Rumford away in Paris until mid-December ${ }^{61}$ together with there being no Managers meeting between 5 October and 7 December, no pressure was applied on Davy for him to fulfil his agreement to provide the lectures.

In January 1802 Davy (1802b) published A Syllabus of a Course of Lectures on Chemistry, commencing on the 21st with his famous lecture 'Discourse Introductory to a Course of Lectures on Chemistry', published subsequently as a pamphlet (Davy 1802c). In this he emphasised the practical value of chemistry to a wide range of processes, including tanning, on which he delivered at least one lecture (Davy 1802b, p. 13; Davy 1802c, pp. 74-78). Rumford commented in February that 'Mr Davy gives universal satisfaction' ${ }^{62}$ and proposed Davy's annual salary be increased to $£ 200 .^{63}$ What is conspicuous by its absence, however, is any reference in either his Discourse or Syllabus to the value of mineralogy although he discussed metallurgy (Davy 1802b, pp. 84-86).

Davy's lectures occupied his time almost exclusively during the first five months of 1802 , his diligence being rewarded with promotion, on Banks's proposal, to Professor of Chemistry. ${ }^{64}$ However, his duties expanded to include providing lectures on agricultural chemistry to the Board of Agriculture (James 2015). As in 1801, when Davy asked leave to investigate tanning for the proposed lecture course, now at the beginning of July he asked the Managers for and was granted leave 'to collect some information that may be useful in the lectures to be given on Agriculture in the Spring'. ${ }^{65}$ But as with 1801, Davy had other intentions and in a letter to the Manchester Chemist William Henry (1774-1836), he said he would be visiting Derbyshire to undertake mineral studies with his friend William Hutchinson (1763-1826) of Eggleston Hall, Co. Durham. ${ }^{66}$ While it could be argued, as Davy did, ${ }^{67}$ that analysing the chemical composition of the underlying geology of a region might be helpful in understanding agriculture processes, the tone of the letter doesn't really suggest this was Davy's main concern. Indeed, in a letter to James Tobin (1767-1814) inviting him

55

George Greenough, Diary, 17 August 1801, UCL MS Greenough/7/4 (no pagination). The stroll is referred to in Carlyon (1836, p. 241).

Davies Giddy, Diary, 17 July, 24, 25 August 1801, CRO MS DG/17. On 20 September 1801 Davy arrived back in London to find Rumford had that day departed for Paris at the start of the Peace of Amiens (Rumford to Joseph Banks, 21 September 1801, RSL MS MM 9.7). In Humphry Davy to Davies Giddy, 14 November 1801, Paris (1831, 1: 129-130), Davy told him he was then in hopes of showing Rumford Trevithick's work.

Humphry Davy to Davies Giddy, 14 November 1801, Paris (1831, 1: 129-130), Davy had left Penzance by 28 August 1801 when Greenough unsuccessfully tried to call on him. George Greenough, Diary, 28 August 1801, UCL MS Greenough/7/4 (no pagination).

She was buried in Nether Stowey on 17 September 1801.

Samuel Taylor Coleridge to Thomas Poole, 19 September 1801, Griggs (1956-1971, 2: 758).

British Mineralogical Society minutes, 29 October 1801, NHM MS SC BRI, p. 86.

Rumford to Joseph Banks, 22 November 1801, Chambers (2007, 5: letter 1609).

Rumford to Marc-Auguste Pictet, 10 February 1802, Bickerton and Sigrist(2000, 3: 571-573).

RI MM, 15 February 1802, 2: 241.

RI MM, 31 May 1802, 3: 43.

RI MM, 5 July 1802, 3: 51-52.

Humphry Davy to William Henry, 21 July 1802, Institution of Engineering and Technology MS SC 3/B/2/32

Humphry Davy to Davies Giddy, 26 October 1802, Paris (1831 1: 156-159). 
to join the tour Davy assured him that fishing (Davy's lifetime pursuit) 'will be a primary object with me in all the summers time' ${ }^{68}$ According to his obituary Hutchinson, a Cambridge trained lawyer, associated 'with the most eminent in rank and talent'. ${ }^{69}$ Interested in botany (Horsman 1998, pp. 116-119) he laid out the gardens at Eggleston Hall and became an Annual Subscriber to the Royal Institution in mid-February $1802,{ }^{70}$ presumably to attend Davy's lectures. The Hutchinson family income came, in part, from exploiting the lead deposits of Teesdale, so examining the mineral deposits around Buxton might have appeared as a valuable experience for Hutchinson.

In late July Davy and Hutchinson left London, by post-chaise, and headed for Derbyshire. In England he visited Matlock, Buxton, Macclesfield, Manchester and Chester before going into Wales. ${ }^{71}$ At some point Hutchinson left and Davy was joined by the Brentford tanner Samuel Purkis (1755-1832), who nearly thirty years later described their walk through Wales. ${ }^{72}$ Both this and Davy's letters written at the time focus on the sublimity of the scenery, although Purkis does refer to Davy fishing and observing rock strata. They traversed Wales from North to South, taking the ferry from Chepstow to Bristol and thus back to London where Davy arrived towards the end of September. ${ }^{73}$

During October Davy began experimenting on soils, some of which he may have collected in Wales, but he also asked Giddy and later Gregory Watt for samples from their areas. ${ }^{74}$ However, needing to prepare around forty lectures to deliver at the Royal Institution during the first five months of 1803 , it was really too late to undertake the work necessary for his first lecture course to the Board of Agriculture and these were postponed until May (James 2015, p. 373). The six lectures then delivered were so popular that in late May and early June he repeated them at the Royal Institution. This repetition appears to have been arranged by Banks on the Royal Institution's behalf without any consultation. Banks attended the Managers' meeting held on 6 June 1803, during the delivery of the course; it would be his penultimate meeting despite having a further two years to serve as a Manager (James 2015, p. 374) - the start of a schism between Banks and the Royal Institution.

Davy, as in the previous two years, requested leave from the Royal Institution during the summer, although on this occasion not making any work-related justification for it. ${ }^{75} \mathrm{He}$ had originally intended to go to Paris and perhaps Geneva, ${ }^{76}$ but Britain declaring war against France on 18 May 1803 following the breakdown of the Peace of Amiens, quickly put paid to that idea. Instead he first visited Holkham Hall on the Norfolk coast, the seat of the well-known agricultural reformer Thomas Coke (1754-1842) a connection doubtless formed through the Board of Agriculture. ${ }^{77}$ After returning to London he left for the West Country on 5 July. ${ }^{78}$ In Penzance he collected a large number of Cornish minerals, despatching them to the Royal Institution in midAugust, before returning to London in early September, on the way spending a few days with Poole in Nether Stowey. ${ }^{79}$

Thereafter it is not clear what Davy did for much of the remainder of the year and into 1804 although he spent three weeks during the autumn with the President of the Board of Agriculture,

Humphry Davy to James Webbe Tobin, 26? July 1802, LU MS ALS Davy H. 1802.

Durham County Advertiser, 23 September 1826, 3a.

RI MM, 15 February 1802, 2: 239.

Humphry Davy to Grace Davy, 1 September 1802, Davy (1836, 1: 267-268).

Published in Paris (1831, 1: 152-156).

Humphry Davy to William Godwin, 26 September 1802, Bodleian Library MS C. 527 c.

Humphry Davy to Davies Giddy, 26 October 1802, Paris (1831, 1: 156-159) and Humphry Davy to James Watt jr, 6 February 1803, LoB MS 3219/6/2/D/6.

RI MM, 6 June 1803, 3: 144.

Humphry Davy to Thomas Poole, 1 May 1803, Paris (1831, 1: 176-177). See also Samuel Taylor Coleridge to

Thomas Poole, 14 December 1801, Griggs (1956-1971, 2: 776-777).

This visit was noted in Annals of Agriculture, 1803, 40: 606.

Humphry Davy to William Allen, 4 July 1803, Allen (1846-1846, 1: 64).

Humphry Davy to William Savage, 13 August 1803, RI MS RI CG/4/1/50. 
John Holroyd, Baron Sheffield (1735-1821), on his Sussex estate.$^{80}$ It is possible that Davy used the severe administrative and financial crisis which the Royal Institution passed through during 1803 to consolidate his position there. ${ }^{81}$ This is evinced by the increasing number of references in the Mangers minutes to Davy's role in the Royal Institution's day to day running, following Rumford's abrupt departure for Paris in May 1802.

The breach between Banks and the Royal Institution continued following the Managers' response to the financial crisis. The Science and Accounts Committees prepared a joint report proposing what the Royal Institution's activities for 1804 should be. Approved by the Managers on 7 November $1803,{ }^{82}$ this report produced significant changes of direction in lecture content and institutional administration. In addition to Davy, the key figures in running the Royal Institution, especially in determining the lecture programme, were the Managers Thomas Bernard (1750-1818) and Charles Hatchett (1765-1847). Under their direction lectures on chemistry and natural philosophy, to be delivered by Davy, Allen and John Dalton (1766-1844), continued. However, additional topics, included covering architectural history, belles lettres, painting and botany. The Royal Institution's expanded lecture programme showed a pronounced shift, maintained in subsequent years, away from practical and utilitarian concerns. This move from the Banksian programme doubtless accounts for Banks complaining angrily to Rumford in Paris that 'the Institution has irrevocably fallen into the hands of the Enemy, \& is now perverted to a hundred uses for which you \& I never intended'. 83

Davy's opening lecture of the new season on 2 February 1804 marked a significant departure from his previous courses. Divided into two, the course covered the connection of chemistry with natural operations (delivered in the afternoon) and artificial operations (delivered in the evening). In the first part Davy dealt basically with the chemistry of the globe including geological phenomena, the oceans, the atmosphere, vegetation and animal life, concluding 'as we are acquainted with only a very minute part of the materials of the globe, there is great reason to suppose, that powers have been, and may be called into action in modifying it, of which we can form no ideas; and which it has pleased the Divine Will to conceal from us in wisdom' (Davy 1804, p. 24). In the second part Davy covered more familiar territory, discussing the properties of various simple and compound chemicals in relation to heat, light and electricity. At one point he discussed the utility of some of these materials for processes such as metallurgy, dyeing, bleaching and so on (Davy 1804, pp. 41-42), but this formed a comparatively small portion of the course. It seems that Davy had decided to move towards stressing the intellectual and scientific, rather than the practical and utilitarian, component of chemistry. There were probably a couple of reasons for this change. First, not even an attractive and entertaining lecturer such as Davy could hope to continue retaining the attention of his audience covering the same material year after year. And, second, probably crucially, such a development adhered closely to the Royal Institution's policy of expanding the range of subjects covered by the lecture programme.

\section{COLLECTING MINERALS}

While the Royal Institution had taken a path that incurred Banks's displeasure, Davy, as an employee, had to follow it and indeed help its implementation. But he needed also to satisfy Banks (to hold onto his patronage) by seeking to retain, or at least appear to, some of the practical and utilitarian aspects of the Royal Institution's initial programme. Indeed, it is possible that Davy may have sought deliberately to subvert, or at least modify, the Royal Institution's new direction, through the development of a significant mineral collection. The joint report referred to 'The foundation of a Mineralogical Collection [that] has been laid, by the exertions of Mr. Professor

$80 \quad$ Humphry Davy to Davies Giddy, October 1803, Paris (1831, 1: 182); Humphry Davy to the Earl of Sheffield, 17 December 1803, East Sussex Record Office SPR1/139/80.

81 John Hippisley to Third Earl of Hardwicke, 9 April 1820, RI MS AD/3/A/1, folder 10 recollected that the crisis nearly led to the Royal Institution's closure.

A copy of the printed text is in RI MS Pep/F/7 approved at RI MM, 7 November 1803, 3: 156.

Joseph Banks to Count Rumford, 6 June 1804, Chambers (2007, 5: letter 1750). 
Davy. ${ }^{84}$ The wording seems to attribute the entire idea to Davy and, at first glance, it might appear peculiar that an organisation in financial difficulty would develop a new activity and one not intended at its foundation. But the report next noted that a Proprietor had offered a $£ 100$ donation to support the collection and that others would give additional mineral specimens. This would have been interpreted by the Managers as opening up a potential new income source for the Royal Institution making the project worth the investment. The Visitors report for 1803 noted that a small (unspecified) sum of money had been expended on the mineral collection and that it contained more than 3000 specimens. ${ }^{85}$

In the New Year the Proprietor who had made the offer, Samuel Solly (circa 1724-1807), sent Davy the promised $£ 100$ suggesting that it might best be used for displaying the Cornish minerals. ${ }^{86}$ Towards the end of January Davy informed the Managers that Henry Englefield (17521822) and Elizabeth Hippisley (1760-1843) had presented specimens of minerals from Italy and Somerset respectively 'for the purpose of increasing the Collection'. ${ }^{87}$ The following month Samuel Boddington (1766-1843) gave the Institution a mineral collection which Davy valued at $£ 150.88$

The developments in the Royal Institution were soon noted by a group of three wealthy mineral collectors all sometime MPs, only one of whom had been previously connected with the institution: John St Aubyn (1758-1839), Charles Francis Greville (1749-1809) and Abraham Hume (1749-1838). St Aubyn, a leading Cornish Freemason, owned St Michael's Mount, which figured strongly in Davy's poetic imagination (Davy 1799a, b), though his seat was at Clowance some six miles east of Penzance. Elected a Royal Institution Life Subscriber in August $1804,{ }^{89}$ he owned the mineral collection formed by John Stuart, 3rd Earl of Bute (1713-1792) and so strong were his mineralogical interests that he refused permission for a cave near Penzance with a roof of crystallised tin to be mined..$^{90}$ Greville, an early Life Subscriber to the Royal Institution, ${ }^{91}$ is best known for passing his mistress, Emma Lyon, later Hamilton (bp.1765-1815), much against her powerless will, onto his uncle William Hamilton (1731-1803), ambassador to Naples (Constantine 2001, pp. 133-153). Greville started his mineral collection in 1773 and in 1799 served as a member of the committee which recommended the British Museum purchase the minerals collected by Hatchett with whom he had been on friendly terms since at least $1796 .{ }^{92}$ Of the trio Hume never subscribed to the Royal Institution, possibly because he was more interested in collecting art than minerals. Between them these three gentlemen owned the largest mineral collections in London aside from the British Museum's. ${ }^{93}$ As well as their mutual collecting interests, they shared for several years the services of Jacques, Comte de Bournon (1751-1825), a French émigré, as curator for their collections; he became an annual subscriber to the Royal Institution in December 1804. ${ }^{94}$

The lead seems to have been taken by Greville who met St Aubyn and Hume on 10 April 1804 to consider forming a national mineral collection. Their original idea was to create 'a distinct establishment' for mineralogy and geology modelled on the Royal Institution's proprietorial and subscription structure. ${ }^{95}$ By early May, Greville had decided to see if the proposed establishment could be incorporated into the Royal Institution to which St Aubyn agreed, with some qualification centring on the privileges or otherwise proprietors would enjoy. ${ }^{96}$ On 5 May this group wrote to

RI MS Pep/F/7, p. 3.

'The Annual Report of the Visitors' for 1803, dated 26 April 1804, tipped in RI MS GM 1: 35-38.

Samuel Solly to Humphry Davy, 5 January 1804, RI MM, 9 January 1804, 3: 193.

RI MM, 23 January 1804, 3: 205.

RI MM, 27 February 1804, 3: 223.

RI MM, 20 August 1804, 3: 323.

George Greenough, Diary, 17 August 1801, UCL MS Greenough/7/4 (no pagination). This surely does not mesh well with Berman's (1978) views on the materialistic motivations of land and mine owners.

RI MM, 25 May 1799, 1: 40.

Charles Hatchett to Charles Greville, 23 May 1796, BL add MS 42071, f.89

For further details on their collections see Cleevely (1983 pp. 253, 136, 158).

RI MM, 3 December 1804, 3: 351.

The decisions of this meeting are noted in a draft in BL MS add 42071, f.112-113.

John St Aubyn to Charles Greville, 5 May 1804; Charles Greville to John St Aubyn, 7 May 1804; John St Aubyn to Charles Greville, 12 May 1804, BL MS add 42071, f.117, 118, 119-120 respectively. 
the Managers outlining their plan to establish the collection, estimating the cost at $£ 4000$ which would be raised by subscription. ${ }^{97}$ The Managers responded to this 'gratifying communication' by appointing Bernard and Hatchett to discuss how to proceed with the proposal, a decision communicated to St Aubyn, Greville and Hume by the Royal Institution's Secretary, John Auriol (1753-1824) and Assistant Secretary William Savage (1770-1843). ${ }^{98}$ At their following meeting the Managers approved the proposal which included employing a mineralogist as well as a chemist in charge of the Assay Office. It was decided to issue and distribute widely, including to various colonial governors and residents mostly in the east, ${ }^{99}$ a printed address seeking financial support. ${ }^{100}$ The text was approved three days later ${ }^{101}$ and the proof agreed in early June. ${ }^{102}$ The address appealed to the utilitarian and imperial value of mineralogy, and concluded by commending the plan which would 'promote the prosperity of the Royal Institution, and at the same time ... contribute to the extension of useful Science, and to the increase of our national Resources'. ${ }^{103}$

The Managers agreed that the Mineralogical Collection would be administered in the same way as the Library. That is, it would be funded by a group of Patrons and the money separately accounted for. If three quarters of the proposed $£ 4000$ had not been raised by 10 April 1805 then the Library and Mineralogical Collection Patrons would be merged into a single committee. ${ }^{104}$ The subscription got off to a good start and by 10 June $£ 992$ had been pledged, with $£ 100$ apiece from Bernard, Greville, Hume, Thomas, Lord Dundas (1741-1820), Thomas Coutts (1735-1822), Shute Barrington (Bishop of Durham, 1734-1826), David Pike Watts (1754-1816) and Richard Sullivan (1752-1806) and fifty pounds each from St Aubyn, Englefield and Richard Pennant, Baron Penrhyn (circa 1737-1808), with the remainder coming from five (much) smaller donations. ${ }^{105}$

Establishing a mineral collection seems to have been an attempt to move the Royal Institution in the opposite direction from the way the lecture programme had developed. It is hard to think that such a proposal could have been made or adopted so quickly, without the basic groundwork that Davy had undertaken since his trip to Penzance the previous summer where he obtained the initial minerals for the collection. One does have to wonder if he played any role in formulating or modifying the proposal made by St Aubyn, Greville and Hume. Davy may have known Greville through his association with the Royal Institution; certainly, Gregory Watt told Davy that he was sending samples from his large-scale experiment replicating the hexagonal structures of basalt to Greville where Davy might see them, so he thought them acquainted. ${ }^{106}$ At the very least, forming a mineral collection, especially in its practical and imperial aspects, might possibly persuade Banks that the Royal Institution (and Davy) had not entirely gone over to the enemy.

Davy, taking advantage of the formation of the new mineral collection, asked for leave in the summer to visit north Britain to gain information on geology and agriculture. ${ }^{107} \mathrm{He}$ attended the Woburn sheep shearing display in mid-June, ${ }^{108}$ but did not leave London for his northern tour until around the beginning of July. He thus missed the Managers meeting where the basis on which

97

John St Aubyn, Charles Greville and Abraham Hume to the Managers of the Royal Institution, 5 May 1804, RI MM, 4 June 1804, 3: 295-299.

RI MM, 7 May 1804, 3: 276. John Auriol to John St Aubyn, Charles Greville and Abraham Hume, 7 May 1804, and copy of minute signed by Savage, BL MS add 42071, f.114-115 and 116.

RI MM, 25 June 1804, 3: 309. For example, see Bengal despatch, 22 August 1804, BL IOR E/4/656, p.281 and Bombay despatch, 22 August 1804, BL IOR E/4/1019, p.483 both of which authorised the collection and forwarding of minerals to England. (NB Berman (1978, p. 90) gave an incorrect reference for the first despatch and the wrong place in the second).

RI MM, 14 May 1804, 3: 278-280.

RI MM, 17 May 1804, 3: 281-282.

RI MM, 4 June 1804, 3: 295.

Royal Institution, Address to the Proprietors, Subscribers, and Others, Respecting the Proposed Mineralogical Collection and Office of Assay, 17 May 1804, RI MS uncatalogued.

RI MM, 2 July 1804, 3: 313-314.

A List of the Subscribers to the Library of the Royal Institution of Great Britain. June 10, 1804, RI MS GB, 1: 27, p. 4.

Gregory Watt to Humphry Davy, 21 March 1804, RI MS HD/26/G/8.

RI MM, 18 June 1804, 3: 304.

Noted in The Morning Chronicle, 20 June 1804, 3a. 
the collection would be established was finally agreed. Davy passed through Cambridgeshire, Lincolnshire, Yorkshire, county Durham, Westmorland and Cumberland before going to Scotland. In Cambridge on 3 July 1804 he became a Fellow Commoner of Jesus College, Coleridge's old College which may explain why Davy sought the connection. Because Davy did not keep his notebooks of this journey chronologically, it is impossible to tell precisely when and in what order he visited various places. ${ }^{109}$ But he geologised on the eastern side of the Pennines where he may have stayed with Hutchinson at Eggleston Hall. ${ }^{10}$ Towards the end of July Davy crossed the Pennines where he saw the Wordsworths at Grasmere and Robert Southey (1774-1843) and his family at Keswick ${ }^{111}$ (but not Coleridge, now in the Mediterranean after an emotional farewell to Davy ${ }^{112}$ ). While in Bristol, Davy had seen the second edition of Wordsworth's Lyrical Ballads (1800, but published January 1801) through the press, but until this visit they had almost certainly never met; and there is no surviving evidence concerning the arrangements for the visit. Nevertheless, Davy and Wordsworth spent almost the entire time walking, so that Dorothy Wordsworth (1771-1855), highly pleased with Davy, hardly saw them. ${ }^{13}$

While in the English northern counties Davy collected 'some good specimens which', as he told Savage from Edinburgh, 'I shall send from Leith addressed to you'. ${ }^{114}$ He also visited Siccar Point, a key site that the Scottish geologist James Hutton (1726-1797) had identified as providing, in his view, unambiguous evidence, for his uniformitarian ideas of geological change. This visit suggests that Davy's geological interests went beyond collecting minerals to seeking to understand the processes that produced them. This theme he continued on the next leg of his journey. Four days after writing to Savage, Davy, now in Glasgow, told his mother, as he had told Savage, that he was going to the Western Highlands and the Hebrides for a month. ${ }^{115}$ Places he visited included Loch Lomond, Ben Nevis, Mull and Staffa, the latter of particular interest because of the hexagonal basaltic pillars on the island. Gregory Watt earlier in the year had sent a paper on the formation of such pillars to the Royal Society of London. Although Watt's paper, read on 20 May, contained mostly experimental results he also described his observations, made during the summer of 1803 , of the columns that occurred on eastern side of the Firth of Clyde (Watt 1804, p. 310). It would not be too surprising if this paper prompted Davy's visit to Staffa and other locations in Scotland to examine the pillars for himself.

\section{DISPLAYING MINERALS}

After about two months away, Davy returned to London on 3 September, writing to his mother that he had 'brought back with me a stock of health, and of information for the labours of the coming season'. ${ }^{116}$ By this time the Royal Institution judged that it had acquired a sufficiently large mineral collection for it to be displayed. A week after Davy's return, the Managers asked him to oversee the planning and obtain an estimate for a mineral display room on the ground floor, accessed via the model room at the building's northern end. ${ }^{117}$ The estimate came in at $£ 18$, which was accepted the following week. ${ }^{118}$ There remained, of course, the issue of how they would be displayed for which Hatchett offered to donate seven cabinets which would hold 4000 specimens, a gift the

\footnotetext{
109 The notebook that contains his geological observations for 1804 is RI MS HD/15/E. But on p.132 he noted copying into it observations made earlier on the journey from a 'red Book'.

RI MS HD/15/E, p. 106.

Robert Southey to John Rickman, 6 August 1804.

Humphry Davy to Samuel Taylor Coleridge, 25 March 1804, Wordsworth Trust, WLMS A / Davy, Humphry, Sir; Samuel Taylor Coleridge to Humphry Davy, 26 March 1804, Griggs (1956-1971, 2: 1101-1103); Samuel Taylor Coleridge to Margaret Beaumont, 26 March 1804, ibid., 1104.

113 Dorothy Wordsworth to Margaret Beaumont, 25 July 1804, Selincourt and Shaver (1967, pp. 493-495).

114 Humphry Davy to William Savage, 20 July 1804, RI MS HBJ/B/3/A.

115 Humphry Davy to Grace Davy, 24 July 1804, Science Museum MS 333/5.

116 Humphry Davy to Grace Davy, 3 September 1804, Davy (1836, 1: 268-269).

117 RI MM, 10 September 1804, 3: 328.

118 RI MM, 17 September 1804, 3: 330.
} 
Managers accepted with alacrity. ${ }^{119}$ Whether the collection already contained that number of specimens is not clear, since the Visitors report for 1804 expressed some concern that the collection had not developed as rapidly as hoped. However, in a slight of hand, they combined the value of the subscriptions and of the collection into one sum of $£ 1500$, disguising, to some extent, how poorly the subscription had been doing. ${ }^{120}$

In early 1805 the Managers received and accepted a new estimate of $£ 186$ for fitting up the collection. ${ }^{121}$ The collection continued to grow and in mid-January 1805 Davy informed the Managers that the minerals he had collected whilst in the north had arrived in London; ${ }^{122}$ Hatchett valued them at more than a hundred guineas. ${ }^{123}$ Later in the month, Davy reported further donations to the collection of fossils from India and hematite specimens from Lancashire. ${ }^{124}$ The Royal Institution mostly formed its collection in this way since it did not have the resources to purchase minerals. For example, the mineral dealer Elizabeth Forster (1735-1816) reported that the Royal Institution had declined to buy the collection of the deceased bullion dealer Jasper Atkinson (circa 1724-1804) which it had been offered for $£ 800 .{ }^{125}$ So the donations made by Dundas, George Legge, 3rd Earl of Dartmouth (1755-1810) and Sarah Aust (1744-1811), among others, were welcomed. ${ }^{126}$

Such was the collection's growth that in early February 1805 the Managers changed the location for its display from the northern end of the building to some former offices behind the Grand Staircase. A much more prominent, larger (32 by 21 feet) and easily accessible space, its allocation illustrates the increasing significance of the collection for the Royal Institution. ${ }^{127} \mathrm{~A}$ joint meeting of Managers and four subscribers who had contributed $£ 50$ or more to the Mineralogical Collections (Greville, Englefield, Barrington and Watts), with Davy present, approved the estimate of $£ 166$ for the necessary modifications to the building and $£ 250$ for cases to house the mineral specimens. The latter amount would be taken from the subscription fund. ${ }^{128}$ At the end of May 1805 plans for the space were approved, ${ }^{129}$ with the work completed by the end of March 1806 when the mineral collection was moved into the new display area. ${ }^{130}$

However, it seems to have been noted in May 1805, that the deadline for raising three quarters of the $£ 4000$ required had passed without that sum being obtained. In line with the agreement made the previous year, proposals were made to amend the Royal Institution's by-laws uniting the Library and Mineral funds. However, issues about whether someone, not a Royal Institution Proprietor, could be a patron of the collection derailed that process. ${ }^{131}$ For the next twelve months the issue became absorbed into a more general overhaul of the by-laws and at the Annual General Meeting of the Proprietors held at the start of May 1806, the mineral collection was combined with the library. ${ }^{132}$

\section{ANALYSING MINERALS}

RI MM, 15 October 1804, 3: 335-336. Presumably these had been used formerly to house Hatchett's minerals that had gone to the British Museum.

'The Annual Report of the Visitors' for 1804, dated 22 April 1805, tipped in RI MS GM 1: 41-44. RI MM, 7 January $1805,4: 3-4$. It is not known why there was a ten-fold increase over the September estimate, unless that minute left off a final number. Certainly, in this minute the figures were spelt out in letters. RI MM, 14 January 1805, 4: 8.

RI MM, 21 January 1805, 4: 21.

RI MM, 28 January 1805, 4: 16.

Elizabeth Forster to Philip Rashleigh, 8 April 1805, Cleevely (2011, pp. 178-180).

RI MM, 4 June 1804, 3: 292; 11 June 1804, 3: 301.

RI MM, 4 February 1805, 4: 22, 11 February 1805, 4: 25-26.

RI MM, 18 February 1805, 4: 28. Presumably Hatchett's cases were no longer deemed sufficient. RI MM, 27 May 1805, 4: 83-84.

RI MM, 24 March 1806, 4: 157-158.

None of this seems to have been recorded in any contemporary documentation, but it was noted in a report on the mineralogical collection the following year. RI MM, 9 June 1806, 4: 193.

RI MS GM, 1 May 1806, 1: 60-61. For the text see the annotated by-laws in RI MS AD/2/A/2/A/1806, p. 47. 
Establishing a mineral collection in the Royal Institution obviously entailed the need to analyse minerals, hence the requirement for an assay office. The month following the decision about where to house the collection, the Managers established a laboratory to analyse 'Ore, Mineral, Soil, or other Substances within the British Dominions' which either they or Davy deemed to be scientifically or publicly important. ${ }^{133}$ Whether this was seen as the Assay Office proposed by St Aubyn, Greville and Hume is not clear. Its remit certainly covered the Royal Institution's mineral collection, but also work for the Board of Agriculture. It is probably not a coincidence that during March Davy started undertaking chemical analyses for the Board, for example of guano, which he presumably performed in the Royal Institution's laboratory (James 2015, p. 377). Seven months later, in October, the beginning a formal folio-sized notebook signalled the laboratory's commencement. In this Davy recorded his analyses of substances, such as on 9 November 1805 some specimens of Prussian blue for Lord Dundas and on 30 December a sample for Greville, ${ }^{134}$ work according well with the reasons for which the Managers had established the laboratory.

But a significant number of Davy's entries in the notebook during November and December 1805 dealt with his analysis of Wavellite. Probably at Babington's suggestion, in November 1804 Davy analysed chemically what was initially thought to be a zeolite discovered near Barnstable by the local physician William Wavell (1750-1829). In 1796 at Babington's request Hatchett had collected specimens of it during his tour of England that year. ${ }^{135}$ Davy concluded initially that it comprised 'Alumina 3 parts, combined with one part of Water of Crystallisation'. ${ }^{136}$ But his Philosophical Transactions paper, read to the Royal Society of London on 28 February 1805, modified this slightly to 'about thirty parts of water and seventy of alumine' (Davy 1805a, p. 161; his emphasis). Reflecting this composition Davy proposed naming it Hydrargillite, but also noted Babington's suggestion of Wavellite (Davy 1805a, p. 162). Also in November 1804 the Rector of Creed, about nine miles SNE from Truro, William Gregor (1761-1817, who in 1791 had discovered what we now call titanium) analysed a mineral from the Stenna Gwynn mine. ${ }^{137}$ In his paper, communicated by Hatchett, read to the Royal Society of London on 4 July 1805 and published in Philosophical Transactions, Gregor noted that the mineral he had analysed was the same as Davy's Wavellite. It is clear from this paper that Gregor and Davy had been in touch and indeed may have met in the spring of 1805 (Gregor 1805, p. 340). ${ }^{138}$ Gregor, unlike Davy, did not regard his analysis as definitive, since he recognised the presence of another substance. However, since quantities of the mineral to which he had access were so small, he could not identify what this might be, though he investigated the possibility of it being either phosphoric or fluoric acid (Gregor 1805, p. 343). ${ }^{139}$ In a letter written shortly after his paper had been read, Gregor went further and commented that 'Mr. Davy's name Hydrargillite will not stand'. ${ }^{140}$ Gregor's paper probably led Davy to re-examine the mineral in November and December 1805 recording the experiments in the Royal Institution's new laboratory notebook. ${ }^{141}$ As a result the following year he told Gregor that he had identified fluoric acid as a constituent of the mineral ${ }^{142}$ which he published in a note to Nicholson. ${ }^{143}$

Later in 1805 Davy published a two-page account in Philosophical Transactions about how to use boracic acid to analyse stone (Davy 1805b). In November on the basis of these two publications, together with two earlier papers, the Royal Society of London awarded Davy its premier, indeed at the time only, medal, the Copley. Not quite the medal's youngest recipient,

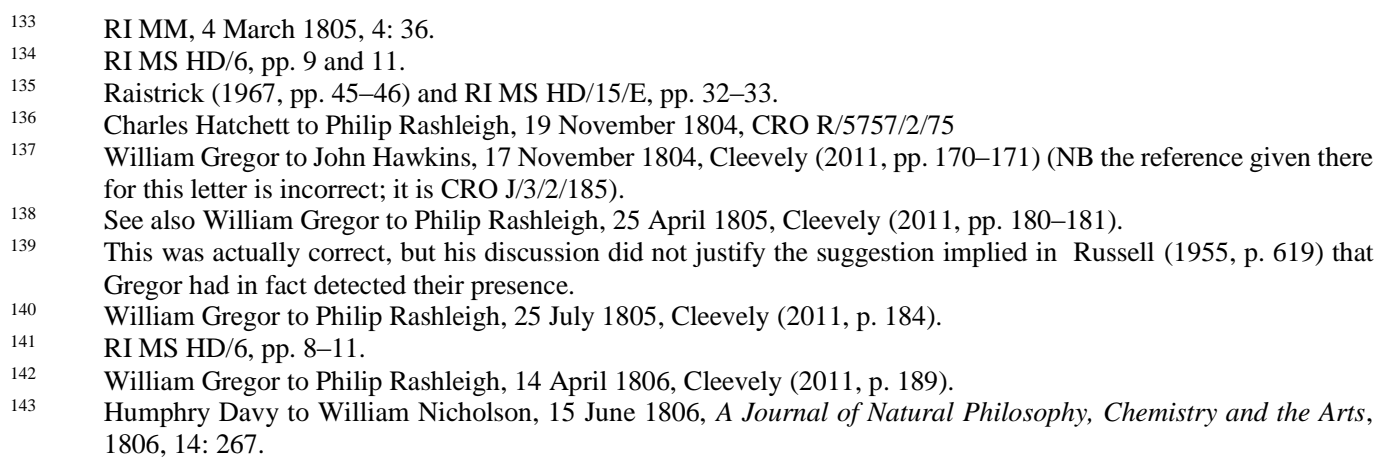


nevertheless at the age of twenty-six this was an impressive achievement, though he would never be awarded it again. The award suggests that he, if not the Royal Institution, was still held in high esteem by Banks. Davy had little option but to continue working at the Royal Institution because of the income it provided. On the other hand, to build his career in science at the very least he needed to ensure that he remained on reasonable terms with Banks and the Royal Society of London. It is clear Davy possessed the necessary skills to negotiate this fraught social space.

\section{LECTURING ON GEOLOGY}

Another consequence of forming a mineral collection was the need to provide an accompanying course of geological lectures at the Royal Institution, so that its Proprietors and Subscribers could see and understand what Davy had acquired. Between February and May 1805 Davy delivered a course of 'Lectures on Geology, or the Chemical History of the Earth' for which the Managers agreed to pay for ten or twelve illustrative paintings at two and half guineas each. ${ }^{144}$ According to Davy these lectures attracted 'very crowded audiences' 145 many of whom would have been Annual Subscribers. Berman (1978, pp. 90-91) attributed an increase in their numbers at the end of 1804 and start of 1805 to the publicity that the mineralogical collection attracted. This seems a bit implausible since nothing was yet on display. More likely the late 1804 increase is attributable to the lecture season beginning a month earlier than in 1803, while that for early 1805 was in line with steadily increasing first quarter figures during the previous four years. In the lectures Davy, using visual illustrations and mineral samples he had collected, stressed the limited extent of current geological knowledge (for example Siegfried and Dott 1980, pp. 70, 113, 115), but, nevertheless, emphasised its practical value to the miner, the engineer, the drainer, the improver of the land and so on (Siegfried and Dott 1980, p. 12): 'The progress of civilization [he opined] is immediately concerned with the application of the metals' (Siegfried and Dott 1980, p. 103). But what is really striking about these lectures is the large quantity of material devoted to the history of science. Mostly Davy's historical passages dealt with classical Greek sources, but he also discussed the contemporary geological debate between Plutonists and Neptunists.

The lecture programme organised by Bernard during the previous and current seasons seems to have been regarded as successful since in early March 1805 the Managers invited him to arrange the 1805-1806 season. ${ }^{146}$ This programme, whilst continuing the policy of expanding the range of topics covered by the Royal Institution, also showed, to a limited extent, a move towards increasing their scientific content and also referred to the practical value of science. Although mostly arranged by Bernard, it seems possible that Davy's influence to some extent lay behind these changes, which accorded well with his development of the mineral collection. If so it would explain the increasing recognition that the Managers gave Davy and suggests that they perceived him as one the Royal Institution's chief assets. His rewards ranged from the minor such as authorising $£ 4$ to be spent on a clothes press for him, ${ }^{147}$ to his significant appointment in early February 1805 as Director of the Laboratory with an additional annual salary of $£ 100$ backdated to the start of the year. ${ }^{148}$

\section{IRELAND}

Davy's support by the Royal Institution Managers continued when they accepted his proposal of travelling through Wales and Ireland making further additions to the mineral collection. Not only granted leave, they provided him with $£ 100$ for expenses and the services of William Payne, the laboratory boy, whose expenses would also be paid. ${ }^{149}$ According to Payne's later account he joined

144 RI MM, 14 January 1805, 4: 9 and 8.

145 Humphry Davy to Thomas Poole, February 1805, Paris (1831, 1: 202-203).

146 RI MM, 4 March 1805, 4: 37.

$147 \quad$ RI MM, 1 April 1805, 4: 53.

148 RI MM, 4 February 1805, 4: 21.

149 RI MM, 20 May 1805, 4: 78. Paris (1831, 1: 204) as William Reeve, but there is no corroborating evidence for this. The Managers support for Davy was not noted either in the accounts or the narrative of 'The Annual Report of the Visitors' for 1805, dated 21 April 1806, tipped in RI MS GM, 1: 55-58. 
Davy, who had left London at the end of June, at Shrewsbury where he found him with a Dr Forbes and Babington suggesting a fishing as well as a geological expedition. ${ }^{150}$ Davy then went into Wales, exploring Snowdonia, ${ }^{151}$ staying (probably) with the agricultural improver and MP for Merioneth, Robert Vaughan (1768-1843). ${ }^{152}$ Passing through Anglesey, they crossed the Irish Sea and landed in Wicklow.

From Wicklow Davy and Payne made their way northwards via Kilkenny ${ }^{153}$ to Dublin, where The Times noted Davy's arrival and the purpose of his journey. ${ }^{154}$ Soon they were on their way to Dundalk and the Irish north-east coast. A contact in Ireland had provided Davy with an introduction to the Anglican clergyman, geologist and agriculture improver William Richardson (1740-1820) (Blackstock 2013) with whom he stayed in Port Rush, Co. Antrim, writing later, 'I never spent a week more agreeably'. ${ }^{155}$ From that base, Davy explored thoroughly the geology of the coast and especially continued the work he had begun in Scotland the previous year by studying the basaltic rock structures of Giant's Causeway. ${ }^{156}$ As a result Davy came to the view that these hexagonal rocks did not lend support to 'either the Plutonic or Neptunian theory'. ${ }^{157}$ Richardson sent the geological samples that Davy had acquired for the Royal Institution's mineral collection to Liverpool, for transmission to London, although most had not arrived by the end of November ${ }^{158}$ and many had still not arrived in May 1806. ${ }^{159}$

Leaving Port Rush, Davy travelled to Belfast ${ }^{160}$ where he crossed the sea to stay with the Wordsworths in Grasmere. Wordsworth read part of the Recluse to him, whilst his sister later described Davy as a 'treasure'. ${ }^{161}$ There he met Walter Scott for the first time ${ }^{162}$ when they and Wordsworth climbed to the summit of Hellvelyn. Davy continued his geological work by comparing the mountains of Cumberland and Westmoreland with those of Wales. ${ }^{163}$ He headed south, through Lancashire and Derbyshire, visiting George Beaumont (1753-1827) and his wife Margaret Beaumont (1756-1829) at Coleorton Hall, near Ashby de la Zouch, Leicestershire. Davy continued writing comparatively about the geology of these counties, including the position of coal. ${ }^{164}$ Arriving back in London towards the end of August ${ }^{165}$ he stayed only a day or two before leaving, with Bernard, ${ }^{166}$ to spend September in Devon and Cornwall. ${ }^{167}$

On his return to the Royal Institution, Davy spent much of October and early November in the laboratory analysing chemically the basalts he had collected in Ireland. ${ }^{168}$ The intensity of this research diminished following the commencement of the Royal Institution's new season with a lecture delivered by Davy on 11 November $1805,{ }^{169}$ though he did spend the occasional day in the laboratory in the ensuing months. ${ }^{170}$ In the New Year Davy repeated his course of ten geology lectures from the previous year. Instead of, or perhaps as well as, displaying drawings, he used

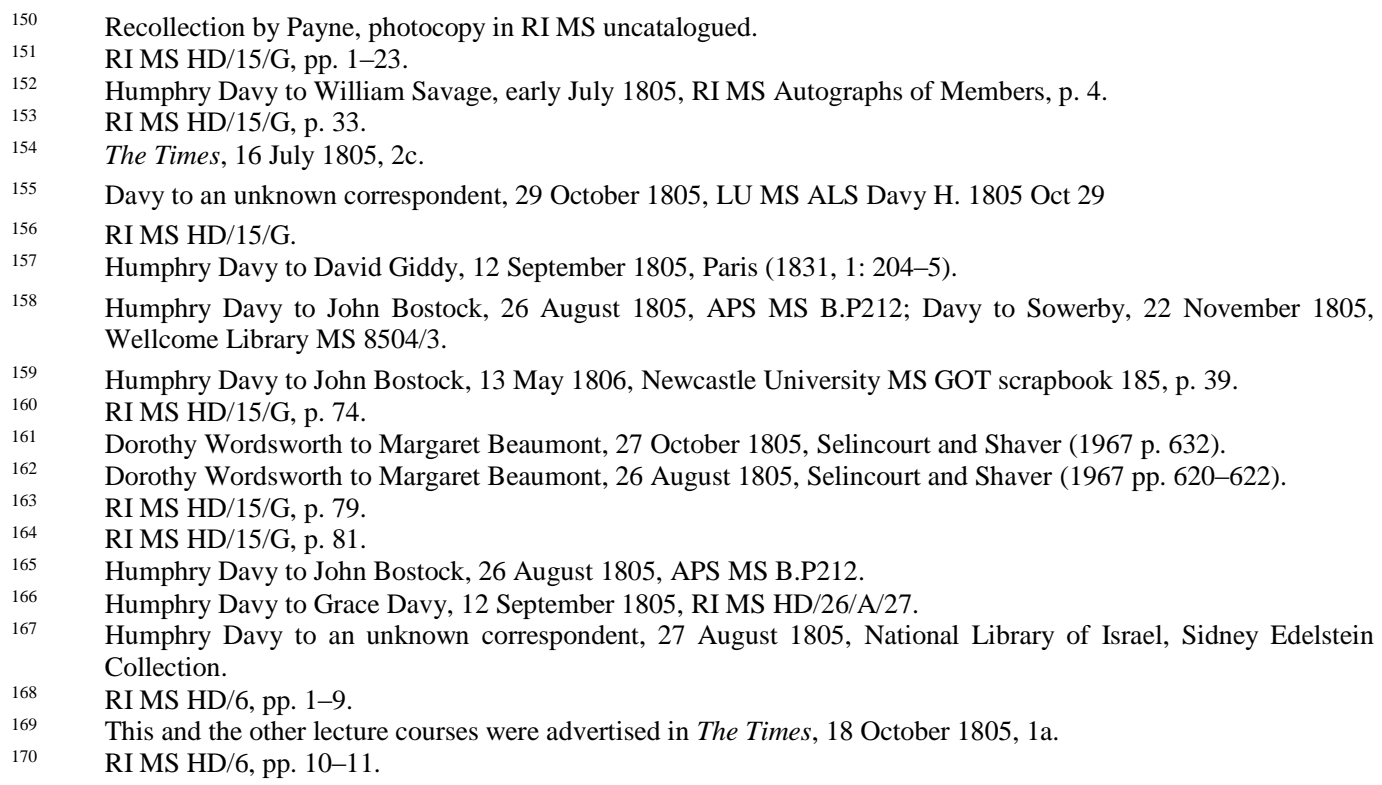


transparencies ${ }^{171}$ - presumably a form of magic lantern. To make them the Managers provided Davy with the help of the assistant librarian paying him an additional ten guineas. ${ }^{172}$ Towards the end of the course, the Managers accepted Davy's proposal that he deliver some additional geological lectures and then spend the remainder of the season in moving and organising the mineralogical collection (a process that began at the end of March ${ }^{173}$ ) instead of delivering a third lecture course. ${ }^{174}$ Furthermore, Davy's expeditions and field experience had given him the confidence to comment on Poole's proposal to exploit a mine near Nether Stowey which Davy hinted was not altogether wise; ${ }^{175}$ another example of the negative use of geological knowledge.

With the mineral collection moved and Davy's lectures to the Board of Agriculture nearing completion, Davy asked the Royal Institution Managers leave to visit the West of Ireland to add further to the collection. As in the previous summers, the Managers approved, agreeing that Davy could have $£ 100$ for this, and the services of Payne whose expenses would be met. ${ }^{176}$ In addition to Payne, Davy was also accompanied to Ireland by Greenough. Leaving London at the start of June, they stayed with the horticulturalist Thomas Knight (1759-1838) at Elton near Ludlow (Davy 1858, p. 124) ${ }^{177}$ before crossing to south-east Ireland. They spent some time in Waterford from where Davy sent some mineral samples to Savage for the Royal Institution's collection. ${ }^{178} \mathrm{He}$ then travelled to the south-west, through Cork to Killarney, which seems to have been the furthest point he reached before turning north-east, through Rathkeale to Limerick (where he admired the women). From this point we have his notebook until towards the end of July. ${ }^{179}$ From Limerick they passed through Nenagh and Athlone to Edgeworthstown where he stayed with the Edgeworth family. Heading north and then north-west through Enniskillen, the party reached Donegal in midJuly, having witnessed 'much riot' on 12 July due to sectarian divisions. ${ }^{180}$ From Donegal they passed through Raphoe and Derry on their way to Port Rush to stay with Richardson where they seem to have spent a week or two, resuming studying the Giant's Causeway. By mid-August they were in Belfast from where Davy told Savage 'I have met with several valuable minerals \& my journey will add considerably to our collection'. ${ }^{181}$ Turning south, the party based themselves in Dublin, exploring the geology there and in Co. Wicklow to the south before returning to London.

\section{THE END OF COLLECTING AND THE START OF ELECTRO-CHEMISTRY}

Fortunately, (or perhaps he planned it), Davy was away from the Royal Institution during June and July 1806. At their meeting on 2 June, the Managers asked Bernard and Hatchett to report on the state of the mineral collection subscription. ${ }^{182}$ The report they presented a week later made depressing reading. They noted thus far that the subscription had reached $£ 942$ ( $£ 50$ lower than reported two years earlier, though they did not make that point), ${ }^{183}$ well below the desired $£ 4000$ target defined exactly two years previously. Of the $£ 942$ St Aubyn, Greville and Hume had

RI MM, 30 December 1805, 4: 129. Some notes for this course are in RI MS HD/15/H, pp. 1-15. RI MM, 3 February 1806, 4: 143 and 5 May 1806, 4: 179.

RI MM, 24 March 1806, 4: 157. Noted in 'The Annual Report of the Visitors' for 1805, dated 21 April 1806, tipped in RI MS GM, 1: 55-58.

RI MM, 24 February 1806, 4: 149.

Humphry Davy to Samuel Purkis, 21 March 1806, Boston University Library, Paul C. Richards Manuscript Collection and Humphry Davy to Thomas Poole, 24 March 1806, Paris (1831, 1: 210-212).

RI MM, 19 May 1806, 4: 183-184.

This gives the date as 1805, but is incorrect as Greenough was touring Scotland that year. Greenough, Diary, 1805, UCL MS Greenough/7/11 and 12 .

Humphry Davy to William Savage, 15 June 1806, RI MS HD/26/D/57.

Davy's notebook covering the middle part of the tour is in RI MS HD/15/B and was published in Davy (1836, 1: 274-291 (the reference to Limerick's women is on p. 275)). The drawings that Davy made, mostly on the Antrim coast, are in RI MS HD/15/A and D. Greenough's surviving Dairy (UCL MS Greenough/7/13) covers the latter part of the expedition.

Davy (1836, 1: 281).

Humphry Davy to William Savage, 13 August 1806, RI MS HD/26/K/5.

RI MM, 2 June 1806, 4: 188.

RI MM, 9 June 1806, 4: 192-194, p. 193. This suggests either an accounting error made by them while preparing their report or that one of the $£ 50$ subscriptions had been returned. 
contributed £250; Proprietors who were already Library Patrons had subscribed $£ 500$ (conditionally, presumably to be paid once pledges for the minimum amount of $£ 3000$ had been received); other Proprietors and Subscribers had provided £192. Furthermore, the report pointed out that St Aubyn, Greville and Hume were not Royal Institution Proprietors and therefore ineligible, under the recently approved by-law changes, to enjoy its privileges. The report concluded: 'their Subscriptions will be returned to them if they think proper; the Managers always retaining a grateful sense of the Benefits which these Gentleman have conferred on the Institution, by suggesting the Idea of a Mineralogical Collection; and by showing that it will be practical to establish and support it out of the Funds of the Institution'. ${ }^{184}$ The Visitors later put the loss occasioned at $£ 4043$ s (presumably for building alterations and cases), noting an additional expenditure on the collection of $£ 250$, which they valued at $£ 1000 .{ }^{185}$ The Managers endorsed the report and ordered a copy to be sent to St Aubyn, Greville and Hume. ${ }^{186}$

The report drew a fairly sharp response, written in Greville's hand, but signed by all three. Starting, without preamble, it referred to 'The total failure of a subscription for an extensive collection of minerals \& for an additional Laboratory of assay'. They claimed that it had never been their intention to use their personal influence to raise the $£ 4000$, and that the sub-committee had thus 'misunderstood' their role. ${ }^{187}$ The unstated implication being they believed it had been the Royal Institution's responsibility to secure the necessary funds. This seems a fairly reasonable position to take since at the beginning of the project the Royal Institution had circulated quite widely the original 'Address'. However, there had been no follow up and one does have to wonder why Davy, who would have known about the difficulties of raising funds from Beddoes's experience for the Medical Pneumatic Institution (James 2016), seems not to have played a role. He may, however, have learnt from this experience, when a few years later he campaigned successfully for money to build a large battery for the Royal Institution (Fullmer 1989). In 1807 Greville and Hume asked, successfully, for the return for both their $£ 100$ subscriptions; ${ }^{188}$ they did not entertain the possibility that they might become Royal Institution Proprietors, the cost of which had risen to 150 guineas. ${ }^{189}$

The rather backhanded comment that their idea showed that the Royal Institution could maintain a mineral collection out of its own resources, really meant that it would remain there, but be rather static with only occasional additions. ${ }^{190}$ A few items from the Royal Institution which had been collected by Davy were used to illustrate British Mineralogy by James Sowerby (1757-1822) (Sowerby 1805-1817, 4: 145; 5: 25, 125). ${ }^{191}$ Following the re-appointment of Michael Faraday (1791-1867) as laboratory assistant in 1815, after his Continental tour with Davy, helping with the mineral collection became one of his duties, but from his letters it is evident that the role did not take up much time (James 1991-2012). ${ }^{192}$ The following year Davy's successor at the Royal Institution, William Thomas Brande (1788-1866), published a catalogue of the collection (Brande 1816). The collection seems simply to have stayed where it was behind the Grand Staircase until the early 1870 s when that area was earmarked for demolition to make way for new laboratories. ${ }^{193}$ At that point the collection, along with other apparatus and objects was disposed of, possibly going to the Geological Museum. ${ }^{194}$

It is evident that the hopes entertained for the collection at the start were not fulfilled, and perhaps could never have been. No longer would Davy go on months long expeditions collecting minerals around the country at the Royal Institution's expense. How far this can be attributed solely

184 RI MM, 9 June 1806, 4: 192-194, quotation on p. 194.

185 'The Annual Report of the Visitors' for 1807, dated 18 April 1808, tipped in RI MS GM 1: 81-84.

186 RI MM, 9 June 1806, 4: 194-195.

187 John St Aubyn, Charles Greville and Abraham Hume to William Savage, second half June 1806, RI MS uncatalogued.

RI MM, 11 May 1807, 4: 260.

RI MS GM, 1 May 1805, 1: 46.

For example, RI MM, 2 December 1822, 6: 365-366.

I am grateful to Professor Paul Henderson for drawing my attention to these references.

RI MM, 15 May 1815, 6: 58 .

James and Peers (2007, p. 162).

RI MM, 4 July 1870, 12: 342, 7 November 1870, 12: 345. Cleevely (1983, p. 251). 
to the new administrative arrangements for the mineral collection is not clear, since during late 1806 and into 1807, Davy commenced new duties. For example, in January 1807 he became one the Secretaries of the Royal Society of London, which restricted how he could use his time. ${ }^{195}$

But also, Davy's research shifted focus from minerals back, for the first time in four years, to electricity, which required the laboratory rather than the field. Following his return from Ireland in late August 1806 Davy spent the bulk of his time working for what would be his first Bakerian lecture at the Royal Society of London to which he was appointed on 13 November 1806 (Davy 1807). ${ }^{196}$ The choice of Davy to deliver this lecture at the age of twenty-seven provides, as with the Copley Medal and his Royal Society of London Secretaryship, further evidence of Banks's continuing support for him. Although the lecture was dated 20 November 1806, its reading continued weekly until 18 December. ${ }^{197}$ Davy devoted the lecture to the chemical phenomena that occurred when electricity passed through various materials. Some experiments that he discussed he had performed originally while in Bristol, but in the Royal Institution's laboratory notebook he recorded the results of 108 experiments that he conducted from late October until mid-November 1806. ${ }^{198}$ In some of these he used mineral samples that he had collected in Cornwall, Wales and the basalts from the North of Ireland (Davy 1807, pp. 10, 15), suggesting a degree of continuity from his geological work during the previous two or three years and, in the search for an explanation of basaltic structure, perhaps the initial motivation to return to electrical research. This long paper (fifty-six printed pages) contained Davy's idea about the relationship of electricity and chemical affinity: 'its [electricity's] relation to chemical affinity is, however, sufficiently evident. May it not be identical with it, and an essential property of matter?' (Davy 1807, p. 39). The query reflected an opening passage of the paper where Davy argued that one problem in understanding the chemical effects produced by electricity was the 'want of analogy to known facts' (Davy 1807, p. 1). By suggesting, albeit tentatively at this stage, the identity of electricity and chemical affinity, Davy provided the analogy he thought wanting and in doing so established the main theme of his and others' electrical research for the future.

\section{CONCLUSION}

Despite the link with his geological work, Davy made no explicit attempt to relate this new electrical research to practical objectives, though he implicitly made a connection when he reported his observation that plant seeds in water germinated more quickly when positive as opposed to negative electricity passed through them - a pale reflection of his earlier views on electricity and life (Davy 1807, p. 53). None of this suggests any sort of straightforward relationship between geology (or indeed any other science) with industrialisation or landowning or imperial ambitions, but a rather complex one needing further empirical elucidation. Indeed, I would suggest that when Davy referred to the practical benefits of understanding the earth, he deployed the rhetoric necessary to secure further support to pursue his scientific investigations in what he regarded as an infant science. There is no evidence which suggests, even remotely, that anything Davy or the Royal Institution did during this period had a practical outcome other than negatively. But it did allow him to undertake three extended journeys round Britain and Ireland which had nothing to do with industrialisation, but which played into his Romantic sensibility and allowed him to become further acquainted with some of the leading Romantics in suitably sublime geological landscapes such as the greywacke rich Hellvelyn.

\section{ACKNOWLEDGMENTS}

\footnotetext{
195 Humphry Davy to Arthur Young, 30 April 1807, BL MS Add 35129, f.400.

196 RSL MS CM, 13 November 1806, 8: 273.

197 Philosophical Magazine, 1806, 26: 266-267 and 269; Allen (1846-1847, 1: 83, diary entry for 18 December 1806). 198 RI MS HD/6, pp. 22-47.
} 
I thank my colleagues on the Davy Correspondence Project, Sharon Ruston, Tim Fulford, Jan Golinski and the late Davy Knight for discussions on Davy which contributed towards this paper. I also thank the archives listed below for permission to study manuscripts in their collections.

\section{ARCHIVES}

Royal Institution (RI), University College London (UCL), British Library (BL), Natural History Museum (NHM), Library of Birmingham (LoB), Cornwall Record Office (CRO), National Library of Scotland (NLS), Lehigh University (LU), the American Philosophical Society (APS), Wedgwood Museum (WM), the Royal Society of London (RSL), the Institution of Engineering and Technology, the Bodleian Library, Morgan Library and Museum, East Sussex Record Office, the Science Museum, Wellcome Library, Institut de France, Newcastle University, the Wordsworth Trust, National Library of Israel and Boston University Library.

Letters written by Humphry Davy are currently freely available on-line at <www.davyletters.org.uk> as part of the project to publish them by the end of the decade. In the meantime, this paper cites their archival or printed locations. Letters from Robert Southey are available at <https://www.rc.umd.edu/editions/southey_letters $>$ and are here cited by author, recipient and date.

The minutes of the meetings of the Royal Institution's Managers are in RI MS AD/2/B/2/A followed by volume number. The minutes of nineteenth-century meetings were published in facsimile as Archives of the Royal Institution, Minutes of the Managers' Meetings, 1799-1903, 15 volumes in 7 (London: Scholar Press, 1971-1976). This is cited here as RI MM followed by date of meeting, volume and page numbers.

Davy's notebooks are in RI MS HD/13, 15, 21, 22 and are thus cited.

\section{REFERENCES}

Allen, William. 1846-1847. Life of William Allen, with selections from his Correspondence. 3 volumes. London: Gilpin.

Amin, Wahida. 2013. The Poetry and Science of Humphry Davy. PhD thesis, University of Salford.

Anderson, Robert G. W. and Jones, Jean (editors). 2012. The Correspondence of Joseph Black. 2 volumes. Farnham: Ashgate.

Anonymous. 1800. [Review of] Thomas Beddoes, Notice of Some Observations made at the Medical Pneumatic Institution, London, 1800 [sic]. The Anti-Jacobin Review and Magazine 6: 424-428.

Averley, Gwen. 1986. The "Social Chemists": English Chemical Societies in the Eighteenth and Early Nineteenth Century. Ambix 33: 99-128.

Berman, Morris. 1978. Social Change and Scientific Organization: The Royal Institution, 17991844. Ithaca: Cornell University Press.

Bickerton, David and Sigrist, René (editors). 2000. Marc-Auguste Pictet 1752-1825 Correspondance Sciences et Techniques Tome III Les Correspondants britanniques. Geneva: Slatkine.

Blackstock, Allan. 2013. Science, politics and society in early nineteenth-century Ireland: The Reverend William Richardson. Manchester: Manchester University Press.

Brande, William Thomas. 1816. A Descriptive Catalogue of the British Specimens deposited in the Geological Collection of the Royal Institution. London: Longman.

Carlyon, Clement. 1836. Early Years and Late Reflections. London: Whittaker.

Chambers, Neil. 2007. (editor). The Scientific Correspondence of Joseph Banks. 6 volumes. London: Pickering.

Cleevely, R. J. 1983.World Palaeontological Collections. London: Mansell.

Cleevely, R. J. 2011. (editor). Collecting the New, Rare and Curious: Letters Selected from the Correspondence of the Cornish Mineralogists Philip Rashleigh, John Hawkins and William Gregor, 1755-1822. Exeter: Devon and Cornwall Record Society. 
Constantine, David. 2001. Fields of Fire: A Life of Sir William Hamilton. London: Weidenfeld \& Nicholson.

Davy, Humphry. 1799a. Ode to St. Michael's Mount. Annual Anthology. Volume I. London: Longman, printed Bristol by Biggs and Co. pp. 172-6.

Davy, Humphry. 1799b. Extract from an unfinished poem upon Mount's-Bay. Annual Anthology. Volume I. London: Longman, printed Bristol by Biggs and Co. pp. 281-6.

Davy, Humphry. 1800. Researches, Chemical and Philosophical; Chiefly Concerning Nitrous Oxide, or Dephlogisticated Nitrous Air, and its Respiration. London: Johnson.

Davy, Humphry. 1801a. 'An Account of some Galvanic Combinations, formed by the Arrangement of single metallic Plates and Fluids, analogous to the new Galvanic Apparatus of Mr. Volta. Philosophical Transactions 91: 397-402.

Davy, Humphry. 1801b. An Account of a new Eudiometer. Journals of the Royal Institution 1: 4548; republished in Philosophical Magazine, 1801, 10: 56-58 and in A Journal of Natural Philosophy, Chemistry and the Arts, 1801, 5: 175-177.

Davy, Humphry. 1802a. Outlines of a View of Galvanism. Journals of the Royal Institution 1: 4966.

Davy, Humphry. 1802b. A Syllabus of a Course of Lectures on Chemistry Delivered at the Royal Institution of Great Britain. London: Royal Institution.

Davy, Humphry. 1802c. A Discourse, Introductory to a Course of Lectures on Chemistry, Delivered in the Theatre of the Royal Institution on the 21st of January, 1802. London: Royal Institution.

Davy, Humphry. 1802d. An Account of a Method of Constructing Simple and Compound Galvanic Combinations, without the use of Metallic Substances, by means of Charcoal and different Fluids. Journals of the Royal Institution 1: 79-120.

Davy, Humphry. 1802e. An Account of some Experiments on Galvanic Electricity, made in the Theatre of the Royal Institution. Journals of the Royal Institution 1: 165-167.

Davy, Humphry. 1802f. Account of some Experiments made in the Laboratory of the Royal Institution, relating to the Agencies of Galvanic Electricity, in producing Heat, and in effecting Changes in different fluid Substances. Journals of the Royal Institution 1: 209214.

Davy, Humphry. 1802g. Observations relating to the Progress of Galvanism. Journals of the Royal Institution 1: 284-290.

Davy, Humphry. 1804. Outlines of a Course of Lectures on Chemical Philosophy. London: Royal Institution.

Davy, Humphry. 1805a. An Account of some analytical Experiments on a mineral Production from Devonshire, consisting principally of Alumine and Water. Philosophical Transactions 95: 155-162.

Davy, Humphry. 1805b. On a Method of analyzing Stones containing fixed Alkali, by Means of the Boracic Acid. Philosophical Transactions 95: 231-232.

Davy, Humphry. 1807. The Bakerian Lecture, on some chemical Agencies of Electricity. Philosophical Transactions 97: 1-56.

Davy, John. 1836. Memoirs of the Life of Sir Humphry Davy, Bart. 2 volumes. London: Longman.

Davy, John (editor). 1858. Fragmentary Remains, Literary and Scientific of Sir Humphry Davy, Bart. London: Churchill.

Evans, John. 1825?. The New Guide, or Picture of Bristol with Historical and Biographical Notices. 3rd edition, Bristol: Lane.

Fullmer, June Z. 1989. Humphry Davy: Fund Raiser. In: The Development of the Laboratory: Essays on the Place of Experiment in Industrial Civilisation, edited by Frank A. J. L. James, 11-21. London: Macmillan.

Fullmer, June Z. 2000. Young Humphry Davy: The Making of an Experimental Chemist. Philadelphia: American Philosophical Society.

Gregor, William. 1805. Experiments on a Mineral Substance formerly supposed to be Zeolite; with some Remarks on two Species of Uran-glimmer. Philosophical Transactions 95: 331-348. 
Grierson, H. J. C. (editor). 1932-1937. The Letters of Sir Walter Scott. 12 volumes. London: Constable.

Griggs, Earl Leslie (editor). 1956-1971. Collected Letters of Samuel Taylor Coleridge. 6 volumes. Oxford: Oxford University Press.

Hartley, Harold. 1966. Humphry Davy. London: Nelson.

Herries Davies, Gordon L. 2007. Whatever is Under the Earth: The Geological Society of London 1807 to 2007. London: The Geological Society.

Hope, Thomas Charles. 1793. Account of a Mineral from Strontian, and of a peculiar Species of Earth which it contains. Transactions of the Royal Society of Edinburgh 4: 3-39.

Horsman, Frank. 1998. Botanising in Linnean Britain: A Study of Upper Teesdale in Northern England. PhD thesis, University of Durham.

James, Frank A.J.L. 1991-2012 (editor). The Correspondence of Michael Faraday. 6 volumes. London: Institution of Electrical Engineers / Engineering and Technology.

James, Frank A.J.L. 1992. Davy in the Dockyard: Humphry Davy, the Royal Society [of London] and the Electro-chemical Protection of the Copper Sheeting of His Majesty's Ships in the mid 1820s. Physis 29: 205-225.

James, Frank A.J.L. 2015. "Agricultural Chymistry is at present in it's infancy": The Board of Agriculture, The Royal Institution and Humphry Davy. Ambix 62: 363-385.

James, Frank A.J.L. 2016. 'the first example ... of an extensive scheme of pure scientific medical investigation': Thomas Beddoes and the Medical Pneumatic Institution in Bristol, 1794 to 1799. London: Royal Society of Chemistry Historical Group Occasional Publication.

James, Frank A.J.L. 2017 The Subversive Humphry Davy: Aristocracy and Establishing Chemical Research Laboratories in Late Eighteenth- and Early Nineteenth-Century England. In: Compound Histories: Materials, Governance and Production, 1760-1840, edited by Lissa Roberts and Simon Werrett, 269-288. Leiden: Brill.

James, Frank A.J.L. and Peers, Anthony. 2007. Constructing Space for Science at the Royal Institution of Great Britain. Physics in Perspective. 9: 130-185.

Knight, David. 1992 / 1996. Humphry Davy: Science and Power. Oxford: Blackwell / Cambridge: Cambridge University Press.

Knight, David. 2009. Chemists get down to Earth. In: The Making of the Geological Society of London, edited by C. L. E. Lewis and S. J. Knell, 93-103. London: The Geological Society.

Lacey, Andrew. 2017. The Chemical Club: An Early Nineteenth Century Scientific Dining Club. Ambix 64: 263-282.

Laudan, Rachel. 1987. From Mineralogy to Geology: The Foundations of a Science, 1650-1830. Chicago: Chicago University Press.

Lloyd, Hattie. 2018. Rulers of Opinion: Women at the Royal Institution, 1799-1812. PhD thesis, University College London.

Lockhart, John Gibson. 1837-1838. Memoirs of the Life of Sir Walter Scott. 7 volumes. Edinburgh: Cadell.

Newcomb, Sally. 1990. Contributions of British Experimentalists to The Discipline of Geology: 1780-1820. Proceedings of the American Philosophical Society 134: 161-225.

Newcomb, Sally. 2009. The World in a Crucible: Laboratory Practice and Geological Theory at the Beginning of Geology. Boulder: Geological Society of America.

Ospovat, Alexander. 1978. Four Hitherto Unpublished Geological Lectures given by Sir Humphry Davy in 1805 from Manuscripts belonging to the Royal Geological Society of Cornwall. Transactions of the Royal Geological Society of Cornwall 21: 1-96.

Paris, John Ayrton. 1831. The Life of Sir Humphry Davy. 2 volumes. London: Colburn and Bentley.

Raistrick, Arthur (editor). 1967. The Hatchett Diary: A tour through the counties of England and Scotland in 1796 visiting their mines and manufactories. Truro: Barton.

Reed, Mark L. 1975. Wordsworth: The Chronology of the Middle Years 1800-1815. Cambridge MA: Harvard University Press.

Rudwick, Martin. 1963. The Foundation of the Geological Society of London: Its Scheme for Cooperative Research and its Struggle for Independence. The British Journal for the History of Science. 1: 325-355. 
Rudwick, Martin. 2005. Bursting the Limits of Time: The Reconstruction of Geohistory in the Age of Revolution. Chicago: Chicago University Press.

Russell, Arthur. 1955. The Rev. William Gregor (1761-1817), discoverer of titanium. The Mineralogical Magazine 30: 617-624.

Russell, Colin A. 1963. The Electrochemical Theory of Sir Humphry Davy. Part III: The Evidence of the Royal Institution Manuscripts. Annals of Science 19: 255-271.

Ruston, Sharon. 2013. From "The Life of the Spinosist" to "Life": Humphry Davy, Chemist and Poet. In: Literature and Chemistry: Elective Affinities, edited by Margaret Hagen and Margery Skagen, 77-97. Aarhus: Aarhus University Press.

Selincourt, Ernest de and Shaver, Chester L. (editors). 1967. The Letters of William and Dorothy Wordsworth: The Early Years 1787-1805. 2nd edition, Oxford: Clarendon Press.

Siegfried, Robert. 1980. Davy's 'Intellectual Delight' and his Lectures at the Royal Institution. In: Science and the Sons of Genius: Studies on Humphry Davy, edited by Sophie Forgan, 177199. London: Science Reviews.

Siegfried, Robert and Dott, Robert H. 1976. Humphry Davy as geologist, 1805-29. The British Journal for the History of Science 9: 219-227.

Siegfried, Robert and Dott, Robert H. (editors). 1980. Humphry Davy on Geology: The 1805 Lectures for the General Audience. Madison: University of Wisconsin Press.

Sigurdsson, Haraldur. 1999. Melting the Earth: The History of Ideas on Volcanic Eruptions. New York: Oxford University Press.

Sowerby, James. 1805-1817. British Mineralogy: or Coloured Figures intended to elucidate the Mineralogy of Great Britain. 5 volumes. London: Taylor / Sowerby.

Spiers C. H. 1968. Sir Humphry Davy and the Leather Industry. Annals of Science 24: 99-113.

Stafford, Robert A. 1989. Scientist of Empire: Sir Roderick Murchison, Scientific Exploration and Victorian Imperialism. Cambridge: Cambridge University Press.

Tann, Jennifer. 1981. The Selected Papers of Boulton and Watt: Volume 1 The Engine Partnership, 1775-1825. Cambridge, MA: MIT Press.

Torrens, Hugh. 1997. Le "Nouvel art de prospection minière" de William Smith et le "Projet de houillère de Brewham": Un essau malencontreux de recherche de charbon dans le sud-ouest de l'Angleterre, entre 1803 et 1810. In: De la géologie à son Histoire: Ouvrage édité en homage à François Ellenberger, edited by Gabriel Gohau, 101-118. Paris: CTHS.

Torrens, Hugh. 1998. Coal hunting at Bexhill 1805-1811: How the new science of stratigraphy was ignored. Sussex Archaeological Collections 136: 177-191.

Torrens, Hugh. 2017. Thomas Beddoes and natural history, especially geology. In: The Enlightenment of Thomas Beddoes: Science, medicine, and reform, by Trevor Levere, Larry Stewart, and Hugh Torrens with Joseph Wachelder, 79-115. Abingdon: Routledge.

Trower, Shelley. 2014. Primitive Rocks: Humphry Davy, Mining and the Sublime Landscapes of Cornwall. Journal of Literature and Science 7: 20-40.

Trower, Shelley. 2015. Rocks of nation: The imagination of Celtic Cornwall. Manchester: Manchester University Press.

Watt, Gregory. 1804. Observations on Basalt, and on the Transition from the Vitreous to the Stony Texture, Which Occurs in the Gradual Refrigeration of Melted Basalt; With Some Geological Remarks. Philosophical Transactions 94: 279-314.

Weindling, Paul. 1979. Geological controversy and its historiography: the prehistory of the Geological Society of London. In: Images of the Earth: New Essays in the History of the Environmental Sciences, edited by Ludmilla Jordanova and Roy Porter, 248-271. Chalfont St Giles: British Society for the History of Science.

Weindling, Paul. 1983. The British Mineralogical Society: a case study in science and social improvement. In: Metropolis and Province: Science in British Culture, 1780-1850, edited by Ian Inkster and Jack Morrell, 120-150. London: Hutchinson.

Wilson, Wendell E. 1994. The history of mineral collecting 1530-1799: with notes on twelve hundred early mineral collectors. Tucson: Mineralogical Record.

Woof, R. S. 1962. Coleridge and Thomasina Dennis. University of Toronto Quarterly 32: 37-54. Wyatt, John F. 1995. Wordsworth and the Geologists. Cambridge: Cambridge University Press. 
Yearley, Steven. 1985. Representing Geology: Textual Structures in the Pedagogical Presentation of Science. In: Expository Science: Forms and Functions of Popularisation, edited by Terry Shinn and Richard Whitley, 79-101. Dordrecht: Reidel.

Contributor Notes:

Frank James is Professor of the History of Science at the Royal Institution and University College London. His main research concentrates on the physical sciences in the late eighteenth and nineteenth centuries and how they relate to other areas of society and culture, for example art, business, media, religion, technology and the military. He edited the Correspondence of Michael Faraday, published in six volumes between 1991 and 2012, and a number of essay collections including 'The Common Purposes of Life' - a set of essays on the Royal Institution. His Michael Faraday: A Very Short Introduction was published in 2010 by OUP who the following year also published his sesquicentenary edition of Faraday's Chemical History of a Candle. His current research is on the practical work of Humphry Davy, including his work on nitrous oxide, agricultural chemistry, mineralogy, the miners' safety lamp, analysis of ancient Roman pigments and his attempts to unroll chemically the papyri excavated from Herculaneum.

He has been President of the British Society for the History of Science, the Newcomen Society for the History of Engineering and Technology, the History of Science Section of the British Science Association and is currently chair of the Society for the History of Alchemy and Chemistry. He was chair of the National Organising Committee for the XXIVth International Congress for the History of Science, Technology and Medicine held in Manchester in July 2013. He was elected a Member of the Academia Europaea in 2012; he is also a Membre Effectif of the Académie internationale d'histoire des sciences and a Liveryman of the Worshipful Company of Scientific Instrument Makers. 